\title{
In vivo therapeutic efficacy of TNF $\alpha$ silencing by folate-PEG-chitosan-DEAE/siRNA nanoparticles in arthritic mice
}

This article was published in the following Dove Press journal:

International Journal of Nanomedicine

\author{
Qin Shi ${ }^{1}$ \\ Elsa-Patricia Rondon- \\ Cavanzo' \\ Isadora Pfeifer Dalla \\ Picola ${ }^{1,2}$ \\ Marcio José Tiera ${ }^{2}$ \\ Xiaoling Zhang ${ }^{3}$ \\ Kerong $\mathrm{Dai}^{4}$ \\ Houda Abir Benabdoune' \\ Mohamed Benderdour' \\ Julio Cesar Fernandes' \\ 'Orthopedic Research Laboratory, \\ Hôpital du Sacré-Coeur de \\ Montréal, Université de Montréal, \\ Montréal, QC, Canada; ${ }^{2}$ Department \\ of Chemistry and Environmental \\ Sciences, UNESP-São Paulo State \\ University, São José do Rio Preto, \\ Brazil; ${ }^{3}$ Orthopedic Cellular and \\ Molecular Biology Laboratories, \\ Institute of Health Sciences, Chinese \\ Academy of Sciences and Shanghai \\ Jiao Tong University School of \\ Medicine, Shanghai, ${ }^{4}$ Department of \\ Orthopedics, Ninth People's Hospital, \\ Shanghai Jiao Tong University School \\ of Medicine, Shanghai, China
}

Correspondence: Mohamed Benderdour Orthopedics Research Laboratory, Research Centre, Hôpital du SacréCoeur de Montréal, Université de Montréal, 5400 Boulevard Gouin Ouest, Montréal, QC H4J IC5, Canada

Tel + I 5143382222 ext 3279

Email mohamed.benderdour@ umontreal.ca
Background: Tumor necrosis factor-alpha ( $\mathrm{TNF} \alpha$ ), a pro-inflammatory cytokine, has been shown to play a role in the pathophysiology of rheumatoid arthritis. Silencing TNF $\alpha$ expression with small interfering RNA (siRNA) is a promising approach to treatment of the condition

Methods: Towards this end, our team has developed a modified chitosan $(\mathrm{CH})$ nanocarrier, deploying folic acid, diethylethylamine (DEAE) and polyethylene glycol (PEG) (folate-PEG$\mathrm{CH}-\mathrm{DEAE}_{15}$ ). The gene carrier protects siRNA against nuclease destruction, its ligands facilitate siRNA uptake via cell surface receptors, and it provides improved solubility at neutral $\mathrm{pH}$ with transport of its load into target cells. In the present study, nanoparticles were prepared with siRNA-TNF $\alpha$, DEAE, and folic acid-CH derivative. Nanoparticle size and zeta potential were verified by dynamic light scattering. Their TNF $\alpha$-knockdown effects were tested in a murine collagen antibody-induced arthritis model. TNF $\alpha$ expression was examined along with measurements of various cartilage and bone turnover markers by performing histology and microcomputed tomography analysis.

Results: We demonstrated that folate-PEG-CH-DEAE ${ }_{15} / \mathrm{siRNA}$ nanoparticles did not alter cell viability, and significantly decreased inflammation, as demonstrated by improved clinical scores and lower TNF $\alpha$ protein concentrations in target tissues. This siRNA nanocarrier also decreased articular cartilage destruction and bone loss.

Conclusion: The results indicate that folate-PEG-CH-DEAE ${ }_{15}$ nanoparticles are a safe and effective platform for nonviral gene delivery of siRNA, and their potential clinical applications warrant further investigation.

Keywords: arthritis, inflammation, siRNA, TNF $\alpha$, nanoparticles, chitosan

\section{Background}

Rheumatoid arthritis (RA), an autoimmune, chronic and systemic inflammatory disorder, is a pathologic condition associated with joint pain, stiffness, ${ }^{1}$ swelling, destruction of cartilage and altered bone structures. ${ }^{2}$ Afflicted patients are prone to fragility fractures due to secondary osteoporosis and bone loss, ${ }^{3}$ and they are likely to have functional disabilities, ${ }^{4,5}$ imposing a huge socioeconomic burden. ${ }^{3}$ Tumor necrosis factor-alpha $\left(\mathrm{TNF} \alpha\right.$ ) has been shown to play a major role in RA pathophysiology, ${ }^{2,6,7}$ especially in joint inflammation with cartilage and bone resorption. ${ }^{6}$ TNF $\alpha$ knockdown improves the inflammatory condition, that is, arthritis, ${ }^{2}$ as demonstrated by treatments targeting it with monoclonal antibody anti-TNF $\alpha .{ }^{7-9}$ Targets such as EP4 receptor, ${ }^{10} \mathrm{C} 5$ and C5aR1 components of the complement system, ${ }^{11}$ and dual-specificity phosphatase $2,{ }^{12}$ among others, are also being investigated to control arthritic inflammation. 
Small interfering RNA (siRNA), a 19-21 nucleotide, double-stranded molecule, could represent an innovative therapeutic approach. ${ }^{13}$ This molecule (average molecular weight $13 \mathrm{kDa}$ ) is large and highly negative charged, and can poorly cross the cellular membranes which are also negatively charged, ${ }^{13,14}$ while also being highly homological to nonspecific targets and very sensitive to RNase degradation. ${ }^{14}$ Therefore, an effective delivery system is needed to enclose siRNA in nanocarriers, protect it against nuclease destruction and transport it to tissues and cells of interest..$^{14,15}$

Different gene vectors, namely, viral ${ }^{14}$ and nonviral systems, ${ }^{16,17}$ have been studied for siRNA delivery inside the cytoplasm of targeted cells. A wide variety of nonviral gene vectors have been proposed over the past few years, including chemical and structural modification of siRNAs, cationic liposomes and polymers, cell-penetrating peptides and targeted delivery. ${ }^{14,18-20}$

Chitosan $(\mathrm{CH})$ and its derivatives are being tested in vitro and in vivo for siRNA delivery because of their good properties as nonviral plasmid DNA delivery systems. ${ }^{21-23} \mathrm{CH}$ is a widely used, biocompatible and biodegradable biomaterial, with low toxicity and immunogenicity. ${ }^{14,24}$ It has been modified with a folic acid ligand to enhance its performance as a gene carrier with transfection efficiency. ${ }^{25}$ In vitro and in vivo transfection with folic acid ligands has been shown to assist $\mathrm{DNA}^{26}$ and siRNA ${ }^{27}$ uptake by folate receptor. To counteract a major drawback of $\mathrm{CH}$ as delivery vector (poor solubility at physiological $\mathrm{pH}$ ), its soluble derivatives containing diethylethylamine (DEAE) have been synthesized and bound to the main chain. ${ }^{28,29}$ In this study, folic acid was bound to DEAE-CH through a polyethylene glycol (PEG) arm.

Collagen antibody-induced arthritis (CAIA) ${ }^{30}$ in mice is a well-known experimental model, as it has characteristics similar to those of RA in humans. In this investigation, CAIA was induced in female DBA/1 mice, which were treated with $\mathrm{CH}-\mathrm{DEAE}_{15} / \mathrm{siRNA}^{\mathrm{TNF}} \alpha$, folate-PEG-CH-DEAE ${ }_{15} /$ siRNA-TNF $\alpha$ or naked siRNA-TNF $\alpha$ carrying the equivalent of $50 \mu \mathrm{g}$ siRNA. Systemic inflammation was assessed by assigning clinical arthritis scores and quantifying TNF $\alpha$ concentrations in arthritic joint tissues. Joints were examined histologically along with markers of bone formation and cartilage destruction. Changes in bone mass, structure and focal bone erosion were ascertained by micro-computed tomography (micro-CT) analysis.

\section{Materials and methods}

\section{Materials}

$\mathrm{CH}$ (degree of deacetylation 85\%) was purchased from Polymar Ciencia E Nutricao (Fortaleza, Brazil). Dulbecco's
Modified Eagle Medium, fetal bovine serum, $0.25 \%$ trypsinEDTA solution, penicillin-streptomycin mixture and agarose were procured from Invitrogen Canada Inc. (Burlington, ON, Canada). Polyethylene glycol 2-aminoethyl ether acetic acid $\left(\mathrm{NH}_{2}\right.$-PEG-COOH), average $\mathrm{Mn} 3,500$, folic acid and other chemicals, if not otherwise stated, were sourced from Sigma-Aldrich Chemical Co. (St Louis, MO, USA). In vivo presigned TNF $\alpha$-targeted siRNA (250 nmol, GenBank accession number: NM_000594.3, Catalog No 4457308, siRNA ID No s202295) was obtained from Ambion Applied Biosystems (Carlsbad, CA, USA): sense 5'-CGU CGU AGC AAA CCA CCA ATT-3', antisense 3'-UUG GUG GUU UGC UAC GAC GTG TG-5'. HeLa cells were purchased from American Type Culture Collection (ATCC, Manassas, VA, USA).

\section{Synthesis of folate-PEG-CH-DEAE conjugate}

$\mathrm{CH}$ derivative $\left(\mathrm{CH}-\mathrm{DEAE}_{15}, \mathrm{MW} 241 \mathrm{kDa}\right)$ was prepared from deacetylated $\mathrm{CH}$, as described in our previous study. ${ }^{28}$ Folate conjugation with $\mathrm{NH}_{2}$-PEG-COOH and folate-PEG conjugation with $\mathrm{CH}-\mathrm{DEAE}_{15}$ were processed as described by Cho et al, ${ }^{31}$ with minor modifications (refer to Scheme 1). ${ }^{32}$

\section{Nanoparticle preparation and characterization}

Nanoparticles were produced on the basis of our previous results (unpublished data, Shi et al, Orthopedic Research Laboratory, Hôpital du Sacré-Cœur de Montréal, 2017). DEAE $_{15}-\mathrm{CH}$ and folate-PEG-CH-DEAE ${ }_{15}$ were dissolved in $\mathrm{HCl}(0.1 \mathrm{M})$. Then, each solution was homogenized in a vortex mixer and heated at $50^{\circ} \mathrm{C}$ for $1 \mathrm{~h}$. The process was repeated until the polymers were dissolved. For further dilution, $25 \mathrm{mM}$ phosphate buffer ( $\mathrm{pH} 6.3$, ionic strength $50 \mathrm{mM}$ ) was included. The final concentration was $9.3 \mathrm{mM}$ for each solution. CH-DEAE 15 / $/$ siRNA and folate-PEG-CH-DEAE $_{15} /$ siRNA complexes were processed at amino groups/phosphate groups (N/P) ratio of $2: 1$ by a coacervation method, with the equivalent of $50 \mu \mathrm{g}$ siRNA in each preparation, as previously described. ${ }^{33-35}$ Particle size and zeta potential were measured by Zetasizer Nano ZS90 (Malvern Instruments Ltd., Malvern, UK).

\section{Cell viability}

HeLa cells were seeded and transfected with free siRNA, CH-DEAE ${ }_{15}$-siRNA or folate-PEG-CH-DEAE ${ }_{15}$-siRNA complexes, followed by $24 \mathrm{~h}$ incubation. Cell viability was then evaluated by MTT colorimetric assay (SigmaAldrich Chemical Co.) based on MTT reduction by NAD(P) 

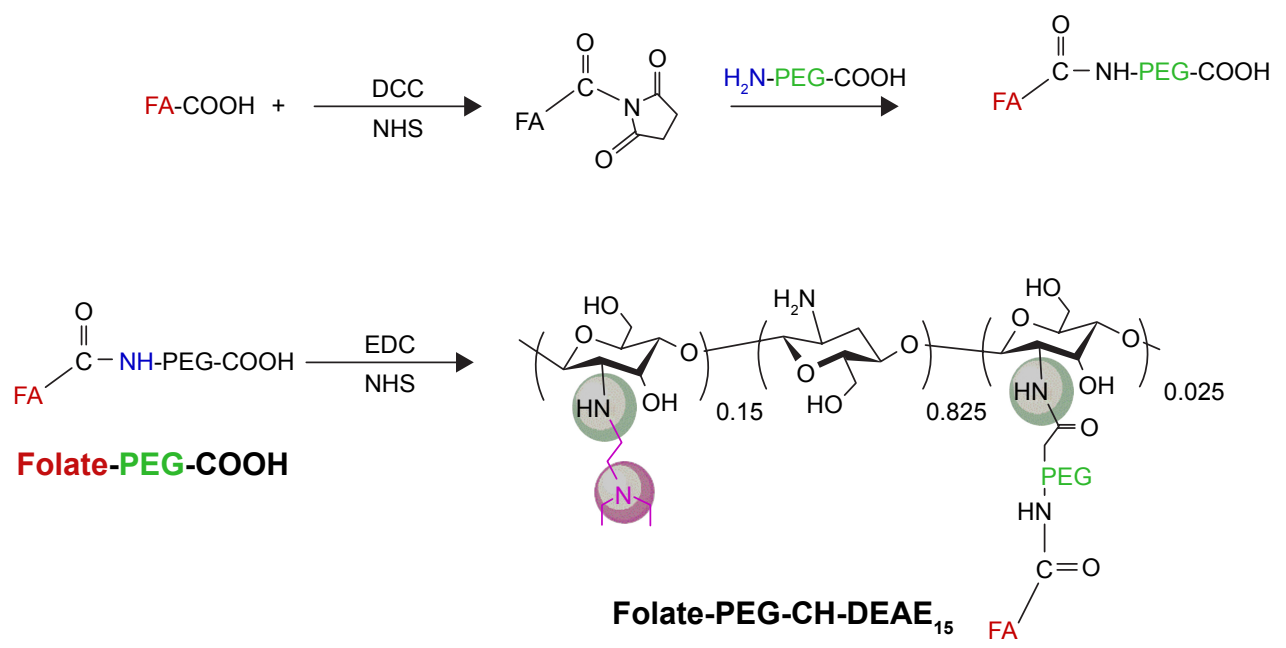

Scheme I Synthetic scheme for the synthesis of the folic acid-labeled diethylaminoethyl-chitosan.

Abbreviations: $\mathrm{CH}$, chitosan; DCC, dicyclohexylcarbodiimide; DEAE, diethylethylamine; EDC, I-ethyl-3-(3-dimethylaminopropyl)carbodiimide; FA, folic acid; NHS, $\mathrm{N}$-hydroxysuccinimide; PEG, polyethylene glycol.

H-dependent cellular oxidoreductase enzymes in viable cells to water-insoluble formazan. Absorbance was measured at $570 \mathrm{~nm}$ with an EL800 universal microplate reader (Bio-Tek Instruments Inc.).

\section{CAIA model}

The study comprised a total of 37 female, 8-12-week-old, DBA/1 mice (Jackson Laboratories, Bar Harbor, ME, USA), which were assigned to five experimental groups, each containing eight mice, except for one group which only had five members. Groups 1 and 2 represented normal and CAIA controls, respectively. Groups 3-5 were nanoparticle treated. All groups were conditioned and manipulated according to Canadian Council on Animal Care guidelines. This experimental protocol was adapted from previously reported methods ${ }^{2,30}$ and approved by the Research Ethics Committee of Hôpital du Sacré-Coeur de Montréal. Disease developed on days 4-5 and reached maximum on days 7-9. Simultaneously, on days $1,3,5$ and 7 , groups $3-5$ received an intraperitoneal injection of $\mathrm{DEAE}_{15}-\mathrm{CH} / \mathrm{siRNA}$ and folate-

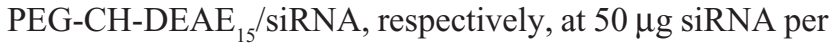
administration. The normal and CAIA groups (groups 1 and 2 , respectively) were given usual saline solution instead. Finally, all mice were sacrificed on day 10. Joint inflammation was measured by arthritic score ${ }^{22}$ on a scale of $0-4$ for each paw $(0=$ normal, $1=$ mild swelling, $2=$ moderate swelling, $3=$ severe swelling of entire paw, $4=$ maximal inflammation), ${ }^{22}$ giving a total score of $0-16$ for all four paws.

\section{Ethics approval}

This study was approved by the Animal Care Committee of the Hôpital du Sacré-Coeur de Montréal Research Centre, in accordance with Canadian Council on Animal Care guidelines. Protocol number: FERJ03.

\section{Specimen selection}

On day 10 , the mice were anesthetized with isoflurane $(3 \%)$, and blood was collected by cardiac puncture before euthanasia. Blood was centrifuged at 3,000 rpm for $10 \mathrm{~min}$, and serum samples were stored at $-80^{\circ} \mathrm{C}$ before use. ${ }^{36}$ Articular tissues $(0.1 \mathrm{~g})$ were harvested in $0.5 \mathrm{~mL}$ lysis buffer and processed by Precellys 24 Homogenizer, according to the manufacturer's instructions. Homogenized tissues were centrifuged and the supernatants preserved and stored at $-80^{\circ} \mathrm{C}$.

\section{TNF $\alpha$ protein levels}

TNF $\alpha$ protein expression was assessed quantitatively with enzyme-linked immunosorbent assay kits from R\&D Systems (Minneapolis, MN, USA), according to the manufacturer's instructions. Mice TNF $\alpha$ protein levels were measured in articular homogenates and reactions were quantified by microplate reader (Molecular Devices Corp., Menlo Park, CA, USA). The detection limit of this assay was $10.9 \mathrm{pg} / \mathrm{mL}$.

\section{Serological marker of cartilage remodeling}

As a marker of cartilage destruction, serum levels of degradation products of C-terminal telopeptide type II collagen (CTX-II) were assessed by Serum Pre-Clinical CartLaps enzyme-linked immunosorbent assay kit from IDS Ltd. (Boldon, Tyne and Wear, UK), according to the manufacturer's instructions. The detection limit of this assay was $1.2 \mathrm{pg} / \mathrm{mL}$. 


\section{Serological markers of bone remodeling}

Alkaline phosphatase (ALP), osteocalcin (OC) and procollagen I N-terminal peptide (PINP) are considered to be biomarkers of bone formation. ${ }^{37}$ Serum ALP activity was quantified as described in a previous study. ${ }^{38}$ Nascent serum OC levels were analyzed by specific enzyme immunoassay (Biomedical Technologies, Inc., Stoughton, MA, USA), according to the manufacturer's instructions. The detection limit of this assay was $0.4 \mathrm{ng} / \mathrm{mL} .{ }^{25}$ Serum PINP was quantified by rat/mouse PINP EIA immunoassay kit from IDS Ltd. The detection limit of this assay was $0.7 \mathrm{ng} / \mathrm{mL}$.

\section{Histologic examination and immunohistochemistry}

Whole knee joint sections were fixed in $10 \%(\mathrm{v} / \mathrm{v})$ formalin and decalcified with $10 \%(\mathrm{v} / \mathrm{v})$ formic acid for $24 \mathrm{~h}$. The specimens were embedded in paraffin, sectioned, and stained with hematoxylin-eosin, ${ }^{25}$ safranin $\mathrm{O}$ and toluidine blue, respectively. Three sections were examined by digital EVOS light microscopy (Electron Microscopy Sciences, Hatfield, PA, USA) at $20 \times$ magnification to evaluate synovitis, bone erosion and cartilage damage. A scoring system, consisting of three grades per condition, as described by Bas et al, ${ }^{39}$ was employed by two investigators blinded to origin of the samples. Synovial inflammation scores were assigned as: $0=$ no inflammation, $1=$ slight thickening of the synovial layer and/or some inflammatory cells in the sub-lining, $2=$ moderate infiltration of the sub-lining and $3=$ markedto-severe infiltration. Bone erosion scores were as follows: $0=$ normal bone, $1=$ small resorption areas, $2=$ numerous resorption areas and $3=$ full thickening of bone resorption areas. Cartilage destruction scores were as follows: $0=$ normal cartilage, $1=$ cartilage surface irregularities, $2=$ minor-tomoderate loss of surface cartilage and $3=$ marked cartilage destruction with loss of surface cartilage. ${ }^{39}$ Tissue sections stained with toluidine blue were evaluated for proteoglycan to estimate cartilage structure condition..$^{40}$

\section{TNF $\alpha$ detection in knee tissues by immunohistochemistry}

Immunohistochemistry included rabbit monoclonal antiTNF $\alpha$ (diluted 1:1,000; HP8001, rabbit IG; Hycult Biotechnology BV, Uden, the Netherlands). The section of TNF $\alpha$ was developed with Dako EnVision + Dual Link SystemHRP (DAB+) kit (Dako, Glostrup, Denmark). Counterstaining involved hematoxylin, and rabbit IgG served as negative control. Briefly, three sections from each femoral condyle and tibial plateau were scored by two investigators blinded to origin of the samples. Total and positively stained chondrocytes were counted and reported as percentages, where $100 \%$ was the maximum score. ${ }^{41}$

Osteoclast activity was observed by tartrate-resistant acid phosphatase (TRAP) staining with leukocyte acid phosphatase kits (Sigma-Aldrich Chemical Co.) following the manufacturer's instructions. Nuclei were counterstained with Gill's hematoxylin (Sigma-Aldrich Chemical Co.), and averages of TRAP-positive osteoclasts were calculated. ${ }^{25}$

\section{Bone assessment and micro-CT analysis}

Mice left hind limbs, from the hip joint to the ankle, were fixed with 4\% paraformaldehyde for three-dimension (3D) micro-CT analysis. Samples were subjected to Skyscan 1176-High Resolution in vivo X-Ray Microtomography (Bruker-MicroCT, Kontich, Belgium) at $50 \mathrm{kVp}$ and $500 \mu \mathrm{A}$ (http://www.skyscan.be/products/1176.htm). The parameters mentioned below were analyzed according to the procedure described by Ibanez et al. ${ }^{42}$ Trabecular bone microarchitecture of the femur was assessed by morphometric indices, such as bone volume/tissue volume (BV/TV, \%), trabecular bone thickness (TbTh, mm), trabecular number ( $\mathrm{TbN}, 1 / \mathrm{mm})$ and trabecular separation (TbSp, mm). Cortical bone was evaluated by bone mineral density (BMD) index $\left(\mathrm{g} / \mathrm{cm}^{3}\right)$.

\section{Statistical analysis}

The data are expressed as means \pm standard error of the means of five to eight mice. All statistics were generated by Prism software (GraphPad Software, San Diego, CA, USA). Statistical significance was assessed by unpaired Student's $t$-test, and $P<0.05$ values were deemed to be significant. ${ }^{25}$

\section{Results}

\section{Nanoparticle characterization}

The sizes of synthesized nanoparticles were $259 \pm 3 \mathrm{~nm}$ for CH-DEAE 15 siRNA with a zeta potential of $+28.3 \pm 0.8 \mathrm{mV}$, and $233 \pm 21 \mathrm{~nm}$ for folate-PEG-CH-DEAE ${ }_{15} / \mathrm{siRNA}$ with a zeta potential of $+34.8 \pm 1.4 \mathrm{mV}$. Nanoparticle $\mathrm{N} / \mathrm{P}$ ratio was $2(\mathrm{~N}=$ polymer amine groups, $\mathrm{P}=$ siRNA phosphate groups).

\section{Cell viability}

The average cell viability of free siRNA or nanoparticletreated cells was $89 \%-97 \%$ compared to nontreated cells (100\%; Figure 1). This result shows no change in cell viability with our synthesized $\mathrm{CH}$-based nanoparticles. These findings indicate that our nanoparticles at the tested dose are safe in cultured cells. 


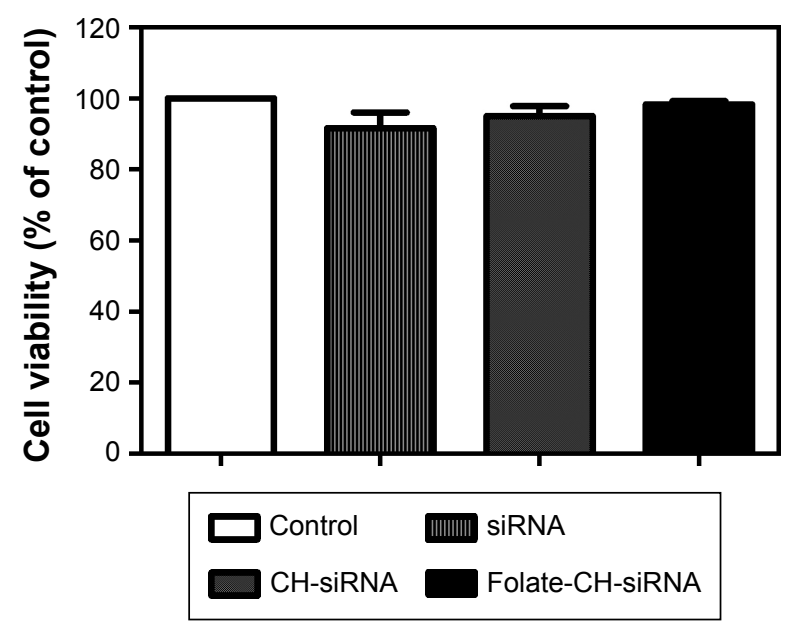

Figure I CH-based nanoparticles did not affect cell viability.

Notes: HeLa cells were treated for $24 \mathrm{~h}$ with $5 \mu \mathrm{g}$ free siRNA-TNF $\alpha, \mathrm{CH}-\mathrm{DEA} \mathrm{E}_{15^{-}}$ $\mathrm{CH} /$ siRNA-TNF $\alpha$ or folate-PEG-CH-DEAE ${ }_{15} /$ siRNA-TNF $\alpha$ complexes containing an equivalent of $5 \mu \mathrm{g}$ siRNA-TNF $\alpha$. Cell viability was evaluated by MTT assay. The results were compared by paired Student's $t$-test and expressed as means \pm SEM for $n=3$.

Abbreviations: $\mathrm{CH}$, chitosan; DEAE, diethylethylamine; PEG, polyethylene glycol; SEM, standard error of the means; TNF $\alpha$, tumor necrosis factor-alpha.

\section{Assessment of disease activity and progression}

Arthritis score (Figure 2A and $\mathrm{B}$ ) and hind paw edema (Figure 2C and D) were evaluated with arthritis severity scores $^{22}$ and digital caliper, respectively. Arthritis developed on day 4, and maximum inflammation was observed between days 7 and 10 (Figure 2A and E). Untreated CAIA mice (group 2) presented progressive arthritis characterized by distinctive redness or inflammation of the limb joints (Figure 2A, C and E) consistent with paw swelling (Figure $2 \mathrm{C}$ and $\mathrm{D}$ ). Clinical arthritic scores on day 10 were significantly less severe in group 4 (folate-PEG-CH-DEAE 15 / siRNA-TNF $\alpha$; Figure 2B). Paw thickness increased significantly in CAIA (group 2) mice on day 10 (Figure 2D and E) and decreased significantly in group 4 . See Table 1 for detailed outcomes. Altogether, our data clearly show that our nanoparticles have antiarthritis properties through reducing the disease activity and scoring.

\section{Histopathologic changes in knee joints}

Knee sections from normal mice (group 1) did not show any histopathologic changes (Figure 3A, left panel). CAIA mice (group 2) displayed marked synovitis (Figure 3A and $\mathrm{B}$ ), bone loss in tibia and femur sections (Figure $3 \mathrm{~A}$ and $\mathrm{C}$ ) as well as cartilage destruction (Figure $3 \mathrm{~A}$ and D). Knee joints from the folate-PEG-CH-DEAE ${ }_{15} / \mathrm{siRNA}^{\mathrm{T} N \mathrm{~T}}$ group (group 4) displayed similar to regular cartilage lining, disclosing significant cartilage improvement (Figure 3A and D), significant prevention of bone destruction (Figure 3C) and significant reduction of joint pathology (synovitis), compared to CAIA mice (group 2), as described in Table 2.

\section{Cartilage remodeling}

Articular cartilage staining was strong in normal mice (group 1; Figure 3A, middle and right panels), as opposed to the weak or absent cartilage staining in CAIA mice (group 2).

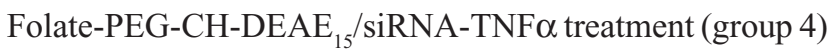
improved cartilage appearance (Figure 3A, middle and right panels). Serum CTX-II concentrations were assessed to quantify cartilage remodeling of mice knees (Table 2). This biomarker gives evidence of articular cartilage condition by predicting its degradation rate. ${ }^{43}$ By day 10 , serum CTX-II levels had increased significantly in CAIA mice (Figure 3E), whereas they were significantly reduced in folate-PEG-CH-

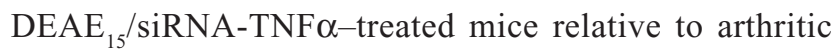
(CAIA) group 2, and were comparable to normal mice. Collectively, our results strongly suggest that our synthetized $\mathrm{CH}$-nanoparticles protect the bone and cartilage in our experimental model of arthritis from structural damages.

\section{Proinflammatory cytokine TNF $\alpha$ profile of joints}

The potential therapeutic effect of folate-PEG-CH-DEAE ${ }_{15} /$ siRNA-TNF $\alpha$ nanoparticles on TNF $\alpha$ concentrations was evaluated in knee tissues, estimating the efficacy of this approach in controlling TNF $\alpha$ expression and its potential impact in RA. TNF $\alpha$ levels in affected knee tissues were significantly higher in CAIA (group 2) compared to the normal (group 1) controls (Figure 4A). TNF $\alpha$ values were significantly decreased in folate-PEG-CH-DEAE $15 / \mathrm{siRNA}^{-}$ $\mathrm{TNF} \alpha$-treated mice (group 4) relative to arthritic group 2 (Table 2). Immunohistochemistry of knee cartilage revealed considerably stronger TNF $\alpha$ staining in CAIA mice (group 2; Figure 4B) than in normal controls (group 1) and folate-PEG$\mathrm{CH}-\mathrm{DEAE} \mathrm{E}_{15} / \mathrm{siRNA}^{\mathrm{TNF} \alpha} \alpha$-treated mice (group 4). The number of TNF $\alpha$-positive cells in articular tissues (black arrows, Figure 4B) returned to normal in group 4 (Figure 4B and $C$ ). Taken together, our data confirm the anti-inflammatory properties of $\mathrm{CH}$-nanoparticles in arthritic mice.

\section{Micro-CT analysis of periarticular bone in knee joints}

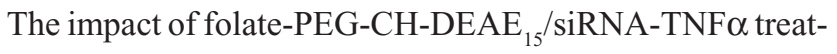
ment on bone destruction was evaluated by $3 \mathrm{D}$ micro-CT analysis in CAIA mice. The results showed reduced 
A
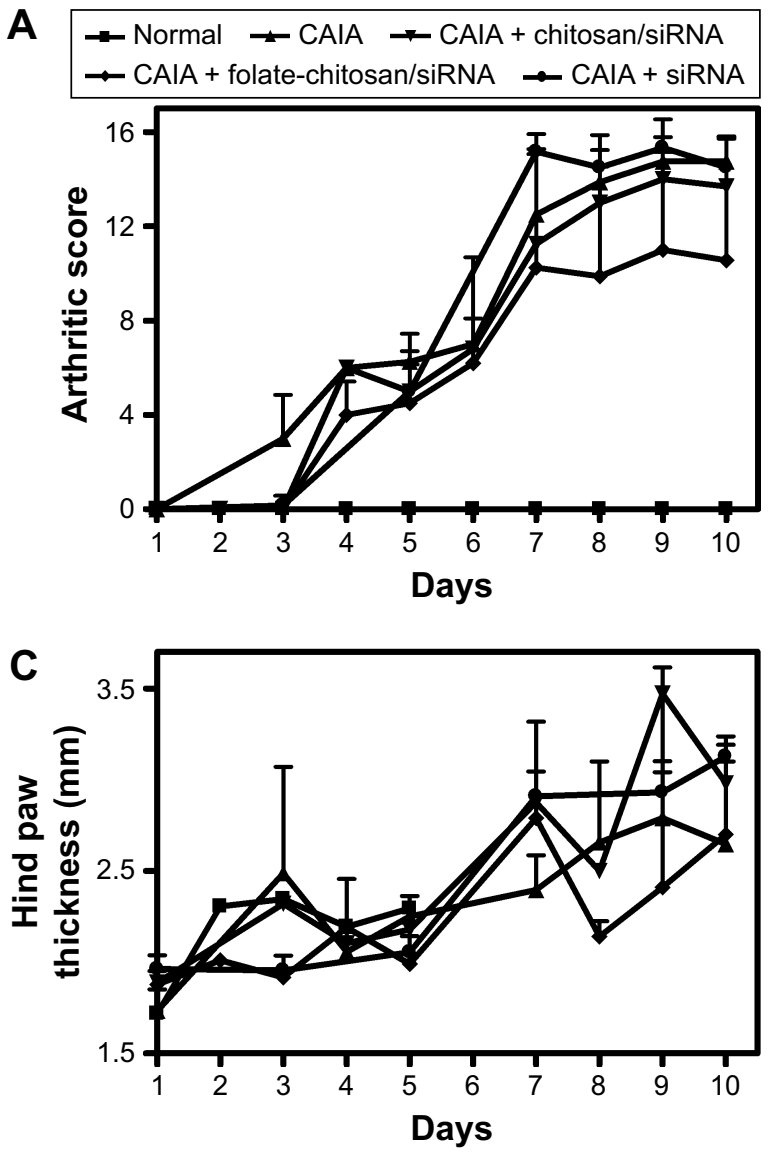

B
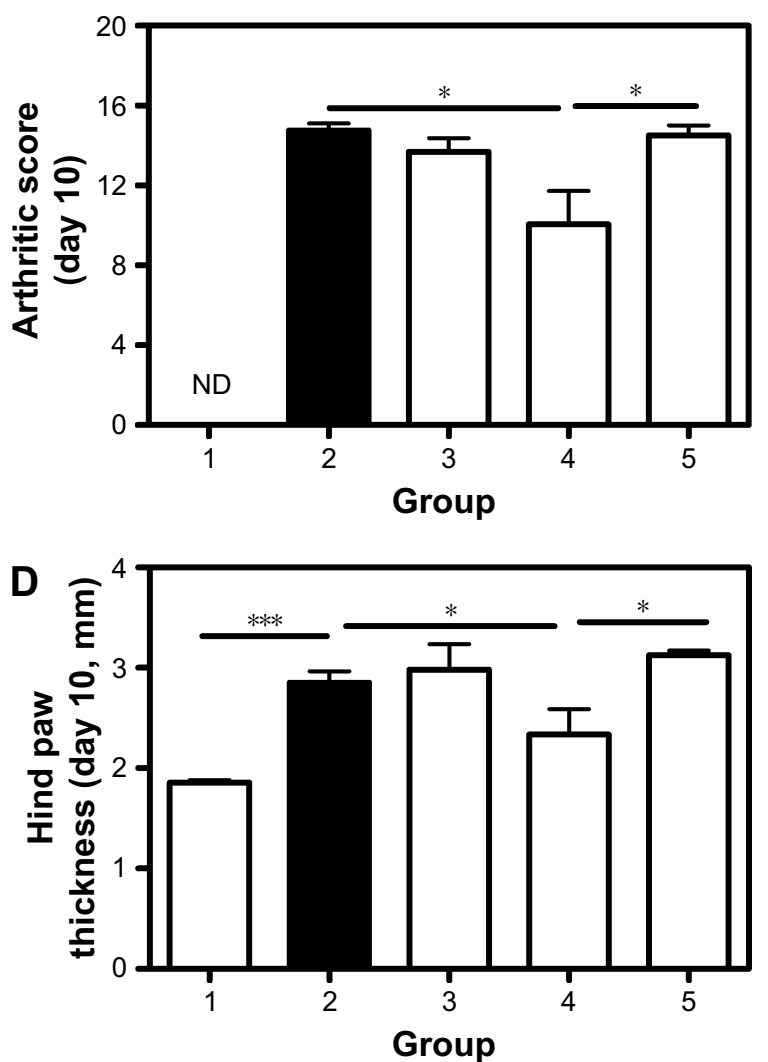

E
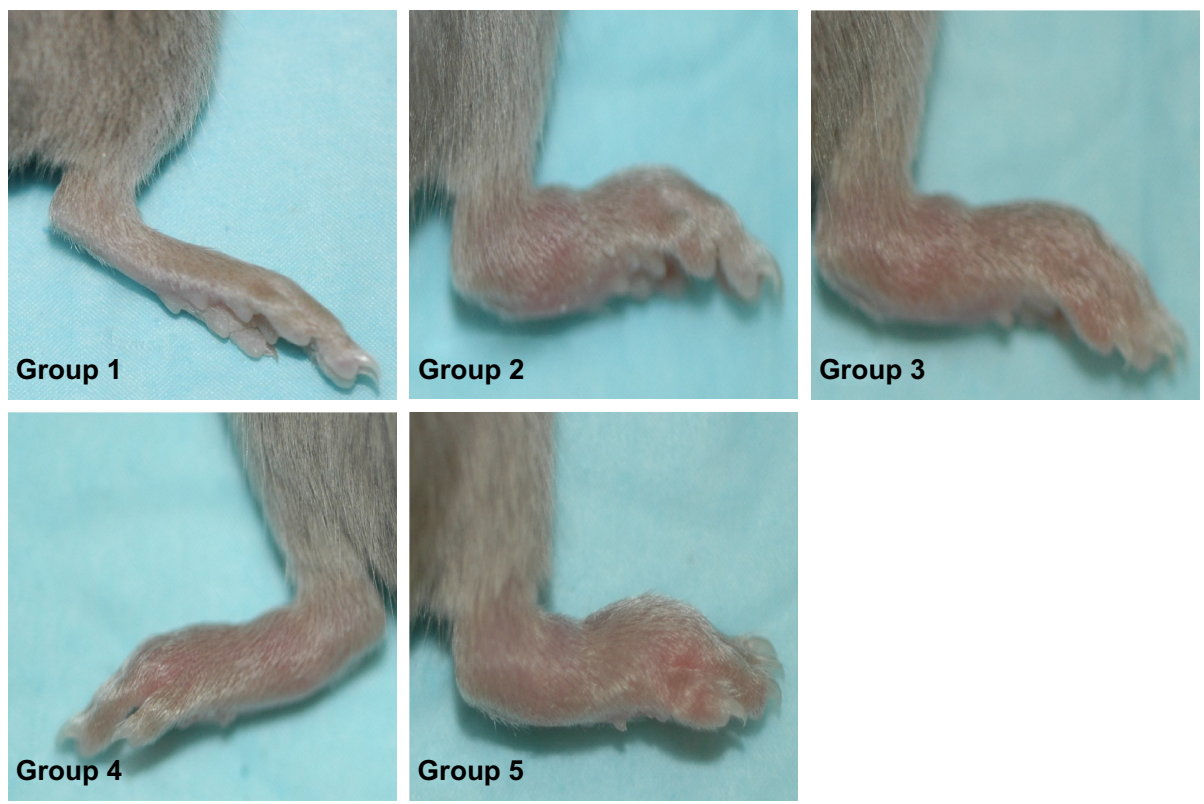

Group 3

Figure 2 Arthritis progression and the therapeutic effects of $C H-D E A E_{15} / s i R N A-T N F \alpha$, folate-PEG-CH-DEAE 15 siRNA-TNF $\alpha$ and naked siRNA-TNF $\alpha$ nanoparticles in a murine CAIA model.

Notes: (A) Joint inflammation in mice was measured by an arthritic scoring method ${ }^{22}$ to verify disease progression on a scale of $0-4$ for each paw, for a total score of $0-16$ for all four paws. On the first day (day I), arthritis was induced by ip injection of a $1.5 \mathrm{mg}$ cocktail of arthritogenic mAb against type II collagen. Two days later (day 3), mice received an ip injection with $50 \mu \mathrm{g}$ Escherichia coli $(0.5 \mathrm{mg} / \mathrm{mL}$ stock) lipopolysaccharide. At the same time on days I, 3, 5 and 7, mice received an ip injection with I00 $\mu \mathrm{L}$ of nanoparticles containing the equivalent of $50 \mu \mathrm{g}$ siRNA-TNF $\alpha$. (B) Arthritic score on day 10. (C) Arthritis development estimated by measuring hind paw thickness over the course of the experiment. (D) Hind paw thickness on day I0. (E) Hind paws of mice on day I0. Statistical significance was assessed by unpaired Student's $t$-test, $* P<0.05$, $* * * P<0.001$. Each group contained eight mice except group 5 which only had five mice. Group I: normal control; group 2: CAIA control; group 3: CAIA mice treated with CH$\mathrm{DEAE}_{15} / \mathrm{siRNA}-\mathrm{TNF} \alpha$ nanoparticles; group 4: CAIA mice treated with folate-PEG-CH-DEAE 15 /siRNA-TNF $\alpha$ nanoparticles; group 5: CAIA mice treated with siRNA-TNF $\alpha$. Abbreviations: CAIA, collagen antibody-induced arthritis; $\mathrm{CH}$, chitosan; DEAE, diethylethylamine; ip, intraperitoneal; mAb, monoclonal antibody; ND, not determined; PEG, polyethylene glycol; SEM, standard error of the means; TNF $\alpha$, tumor necrosis factor-alpha. 
Table I Arthritis and therapeutic effects in mice on day 10

\begin{tabular}{lll}
\hline $\begin{array}{l}\text { Animal } \\
\text { groups }\end{array}$ & $\begin{array}{l}\text { Arthritis score } \\
(\mathbf{0}-16)\end{array}$ & $\begin{array}{l}\text { Hind paw } \\
\text { thickness }(\mathbf{m m})\end{array}$ \\
\hline Group I & 0.0 & $1.86 \pm 0.03$ \\
Group 2 & $14.75 \pm 0.37$ & $2.85^{\mathrm{a}} \pm 0.11$ \\
Group 3 & $13.69 \pm 0.69$ & $2.98 \pm 0.25$ \\
Group 4 & $10.06^{\mathrm{b}} \pm 1.67$ & $2.33^{\mathrm{b}} \pm 0.25$ \\
Group 5 & $14.50^{\circ} \pm 0.50$ & $3.12^{\mathrm{c}} \pm 0.04$ \\
\hline
\end{tabular}

Notes: Group I: normal control; group 2: CAIA control; group 3: DEAE ${ }_{15}-\mathrm{CH} /$ siRNA-TNF $\alpha$-treated mice; group 4: folate-PEG-CH-DEAE ${ }_{15} /$ siRNA-TNF $\alpha$-treated mice; group 5: siRNA-TNF $\alpha$-treated mice. The data are expressed as means \pm SEM. Groups 1-4: eight mice each; group 5: five mice. ap $<0.001$ compared to normal mice. ${ }^{b} P<0.05$ compared to CAIA mice. ${ }^{c} P<0.05$ compared to group 4 .

Abbreviations: CAIA, collagen antibody-induced arthritis; $\mathrm{CH}$, chitosan; DEAE, diethylethylamine; PEG, polyethylene glycol; SEM, standard error of the means; TNF $\alpha$, tumor necrosis factor-alpha.

trabecular bone (Figure 5A), lower cortical BMD (Figure 5B) and BV\% (Figure 5C), with decreased TbSp (Figure 5F) in CAIA mice (group 2), whereas TbTh (Figure 5D) and $\mathrm{TbN}$ (Figure 5E) remained unchanged, compared to normal controls. The significant diminution of BV/TV (Figure 5C) in CAIA mice (group 2) indicates marked bone loss in the trabecular region of the tibia compared to the controls (group 1). Folate-PEG-CH-DEAE 15 /siRNA-TNF $\alpha$ treatment (group 4) increased tibia cortical BMD compared to CAIA mice (group 2, $P=0.133$; Figure 5B). In addition, it restored the trabecular thickness loss observed in CAIA mice. The parameters TbN (Figure 5E) and TbSp (Figure 5F) remained unchanged after treatment compared to the CAIA group (group 2). These findings are in accordance with those of histologic analysis and confirm the protective effect of CHnanoparticle against bone loss in arthritic mice.

\section{Serum ALP, OC and PINP}

Bone formation declines in RA..$^{37,44}$ Therefore, we looked at the effect of folate-PEG-CH-DEAE ${ }_{15} / \mathrm{siRNA}^{\mathrm{T}} \mathrm{TNF} \alpha$ treatment on bone turnover markers. Serum ALP activity declined significantly in CAIA mice (group 2), compared to the normal controls (group 1; Figure 6A). Folate-PEGCH-DEAE $15 /$ siRNA-TNF $\alpha$ treatment (group 4) significantly increased the levels of the enzyme compared to arthritic mice (group 2). Serum OC levels were significantly higher in the CAIA group than in the normal controls (Figure 6B). FolatePEG-CH-DEAE 15 / $/$ RNA-TNF $\alpha$ treatment had a significant protective impact by reducing OC levels compared to the CAIA group. Interestingly, PINP values in CAIA mice were $P=0.65$ compared to the normal controls (Figure 6C). FolatePEG-CH-DEAE 15 /siRNA-TNF $\alpha$ treatment significantly elevated serum PINP levels in comparison to CAIA and control mice (Table 3). These results strongly indicate that
$\mathrm{CH}$-nanoparticles restore bone formation and abolish bone resorption, as indicated by ALP, OC and PINP levels.

\section{Serum TRAP levels and staining}

Serum TRAP levels and TRAP-positive cells in damaged bone areas are characteristic of arthritis. ${ }^{45}$ Serum TRAP activity increased significantly (19.7-fold) in CAIA mice (group 2) compared to the normal controls (group 1; Figure 6D). FolatePEG-CH-DEAE ${ }_{15} / \mathrm{siRNA}^{\mathrm{TN}} \alpha$ decreased TRAP by $1.5-$ fold ( $P=0.12$ ). In addition, TRAP-positive cells were found in periarticular bone sections, along with multinuclear osteoclasts, in CAIA mice joints (group 2) compared to the normal controls (Figure 6E and F). The number of TRAP-positive cells in bone marrow spaces was strongly inhibited in folatePEG-CH-DEAE 15 /siRNA-TNF $\alpha$-treated mice (group 4) compared to group 2 (CAIA) mice (Table 3). Collectively, the inhibition of TRAP activity by CH-nanoparticle administration suggests their anti-osteoclastogenesis properties in arthritic mice.

\section{Discussion}

Gene knockdown by siRNA has been gaining interest in the framework of gene therapy. Modified CH nanocarriers have been considered as effective platforms to enclose and deliver plasmid DNA and siRNA in vitro ${ }^{24,46,47}$ and in vivo. ${ }^{22}$ In this study, $\mathrm{CH}$ was modified with DEAE groups and folic acid-targeting ligands. DEAE ligands increased the colloidal stability of $\mathrm{CH}$ nanoparticles because of their hydrophilicity and capacity to stay protonated in part under physiological conditions. ${ }^{28}$ Uptake efficiency may be enhanced by achieving balance between interaction strengths and augmented colloidal stability. ${ }^{28,29}$ To date, no in vivo folate-PEG-CH-

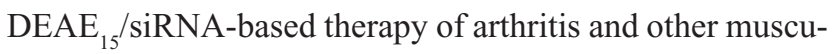
loskeletal disorders has been developed.

A murine RA model was tested in this study to evaluate the efficacy of folate-PEG-CH-DEAE ${ }_{15} / \mathrm{siRNA}^{-T N F} \alpha$ nanoparticles. This approach can significantly decrease inflammation-induced articular cartilage damage and bone destruction, as indicated by $\mathrm{TNF} \alpha$ protein reduction in affected arthritic tissues. We chose the murine CAIA model because of its rapid disease onset, ${ }^{30}$ which occurs within a few days and resembles the RA seen in humans. ${ }^{1}$ The therapeutic effects of folate-PEG-CH-DEAE ${ }_{15} /$ siRNA nanoparticles targeting TNF $\alpha$ demonstrated significant inhibition of inflammation in comparison to untreated controls (Figure 2).

Experimental evidence suggests that functional blockage of TNF $\alpha$ controls CAIA development. ${ }^{2}$ We hypothesized that TNF $\alpha$ knockdown, with folate-CH nanocarriers, could 

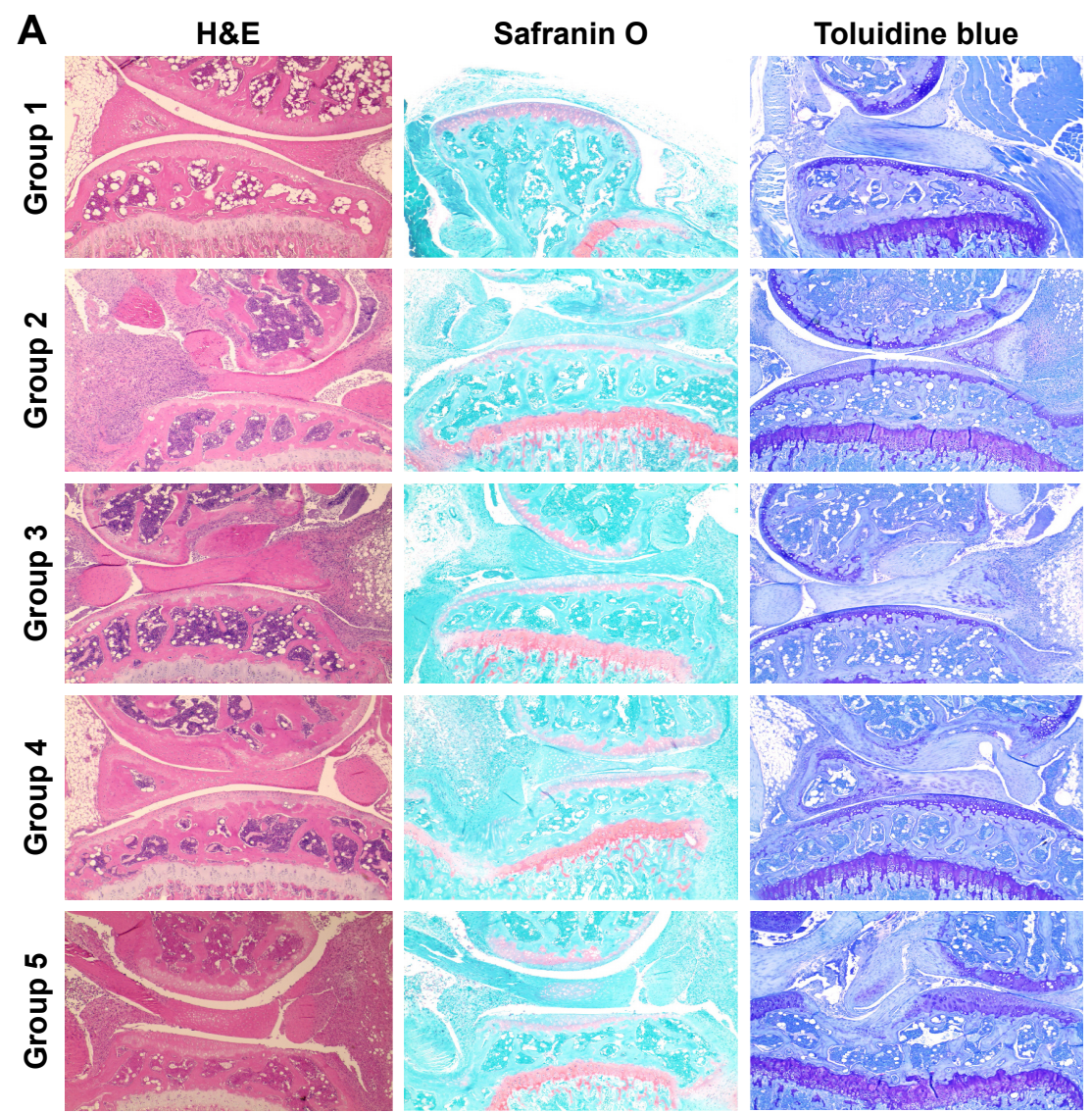

B

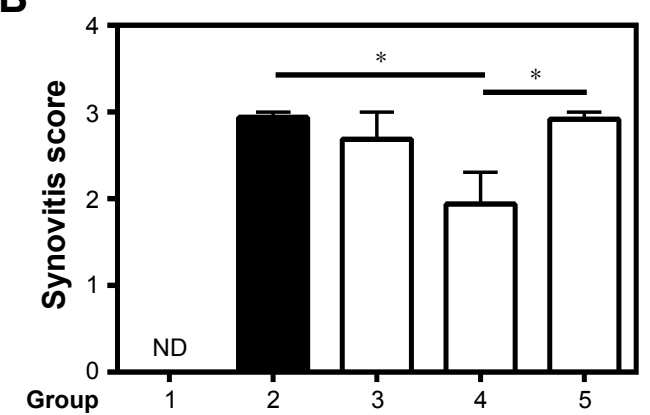

D

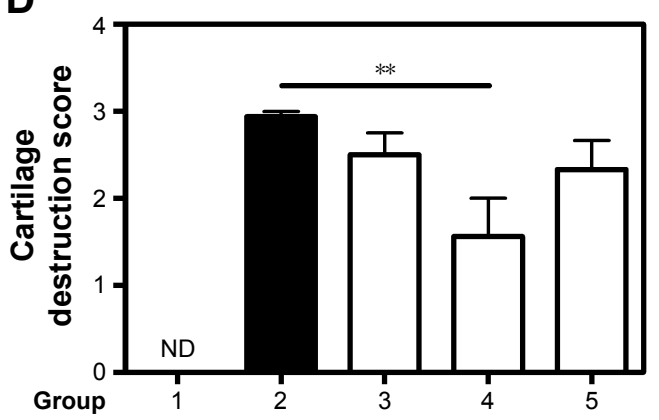

C

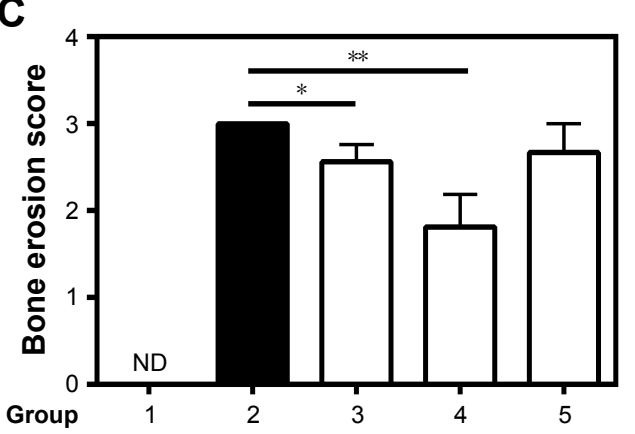

E

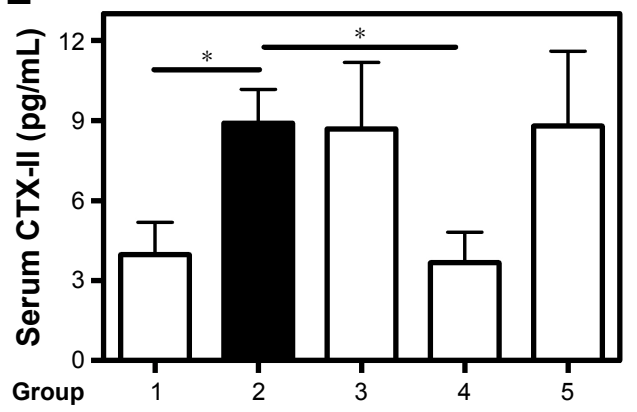

Figure 3 Histologic examination and cartilage destruction marker.

Notes: (A) Hematoxylin-eosin-, safranin O- and toluidine blue-stained images of the hind knee joints of mice from different groups. Knee sections were fixed, sectioned, stained and finally observed by light microscopy at $20 \times$ magnification. Severity scores of (B) synovitis, (C) bone erosion and (D) cartilage destruction were assessed on day 10 by two investigators blinded to origin of the samples and using the already-described scoring method. ${ }^{39}$ (E) Serum levels of CTX-II degradation products measured by ELISA. Values are the means \pm SEM of eight mice (groups I-4) and five mice (group 5). Statistical significance was assessed by unpaired Student's $t$-test, $* P<0.05$, $* * P<0.0$ I. Group I: normal control; group 2: CAIA control; group 3: CAIA mice treated with CH-DEAE 15 siRNA-TNF $\alpha$ nanoparticles; group 4: CAIA mice treated with folate-PEG-CH-DEAE ${ }_{15}$ siRNA-TNF $\alpha$ nanoparticles; group 5: CAIA mice treated with siRNA-TNF $\alpha$.

Abbreviations: CAIA, collagen antibody-induced arthritis; CH, chitosan; CTX-II, C-terminal telopeptide type II collagen; DEAE, diethylethylamine; ELISA, enzyme-linked immunosorbent assay; ND, not determined; PEG, polyethylene glycol; SEM, standard error of the means; TNF $\alpha$, tumor necrosis factor-alpha. 
Table 2 Histologic examination scores, CTX-II and TNF $\alpha$ levels

\begin{tabular}{|c|c|c|c|c|c|c|}
\hline & $\begin{array}{l}\text { Synovities } \\
\text { score }(0-3)\end{array}$ & $\begin{array}{l}\text { Bone erosion } \\
\text { score }(0-3)\end{array}$ & $\begin{array}{l}\text { Cartilage destruction } \\
\text { score }(0-3)\end{array}$ & $\begin{array}{l}\text { Serum CTX-II } \\
(\mathrm{pg} / \mathrm{mL})\end{array}$ & $\begin{array}{l}\text { Knee TNF } \alpha \\
(\mathrm{pg} / \mathrm{mL})\end{array}$ & $\begin{array}{l}\text { TNF } \alpha+ \\
\text { cells }(\%)\end{array}$ \\
\hline Group I & 0.0 & 0.0 & 0.0 & $3.98 \pm 1.21$ & $7.19 \pm 0.36$ & $30.53 \pm 2.59$ \\
\hline Group 2 & $3.00 \pm 0.01$ & $3.00 \pm 0.01$ & $2.94 \pm 0.06$ & $8.90^{\mathrm{a}} \pm 1.27$ & $13.08^{\mathrm{b}} \pm 0.80$ & $64.48^{c} \pm 3.11$ \\
\hline Group 3 & $2.68 \pm 0.31$ & $2.56^{\mathrm{d}} \pm 0.20$ & $2.50 \pm 0.25$ & $8.68 \pm 2.50$ & $10.38^{d} \pm 0.77$ & $61.05 \pm 4.36$ \\
\hline Group 4 & $1.93^{\mathrm{d}} \pm 0.37$ & $1.8 \mathrm{I}^{\mathrm{e}} \pm 0.38$ & $1.56^{\mathrm{e}} \pm 0.44$ & $3.67^{\mathrm{d}} \pm 1.15$ & $9.78^{d} \pm 0.90$ & $33.04^{f} \pm 5.14$ \\
\hline Group 5 & $2.98^{g} \pm 0.01$ & $2.66 \pm 0.33$ & $2.33 \pm 0.33$ & $8.80 \pm 2.80$ & 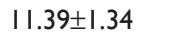 & $63.08^{h} \pm 3.74$ \\
\hline
\end{tabular}

Notes: Group I: normal control; group 2: CAIA control; group 3: CH-DEAE 15 siRNA-TNF $\alpha$-treated mice; group 4: folate-PEG-CH-DEAE 15 siRNA-TNF $\alpha$-treated mice; group 5: siRNA-TNF $\alpha$-treated mice. The data are expressed as means \pm SEM. Groups I-4: eight mice each; group 5: five mice. aP $<0.05$ compared to normal mice. ${ }^{b}<0.01$ compared to normal mice. ${ }^{c} P<0.00$ I compared to normal mice. ${ }^{d} P<0.05$ compared to CAIA mice. ${ }^{e} P<0.01$ compared to CAIA mice. ${ }^{\prime} P<0.00$ I compared to CAIA mice. $8 \mathrm{P}<0.05$ compared to group 4 . ${ }^{\mathrm{h} P}<0.00 \mathrm{I}$ compared to group 4 .

Abbreviations: CAIA, collagen antibody-induced arthritis; $\mathrm{CH}$, chitosan; $\mathrm{CTX}$-II, C-terminal telopeptide type II collagen; DEAE, diethylethylamine; PEG, polyethylene glycol; SEM, standard error of the means; TNF $\alpha$, tumor necrosis factor-alpha.

A

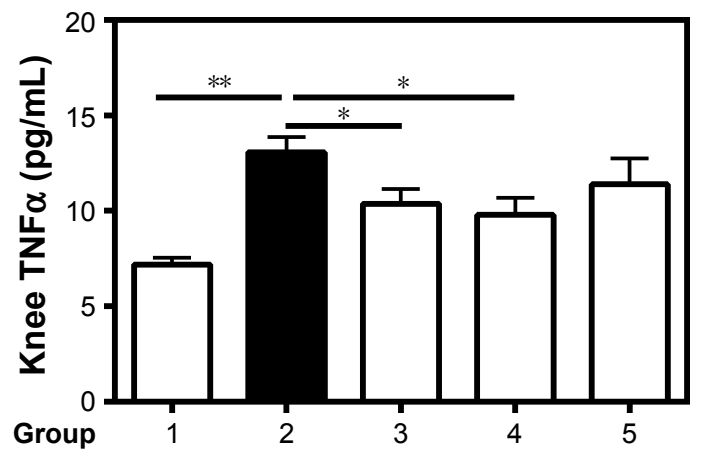

C

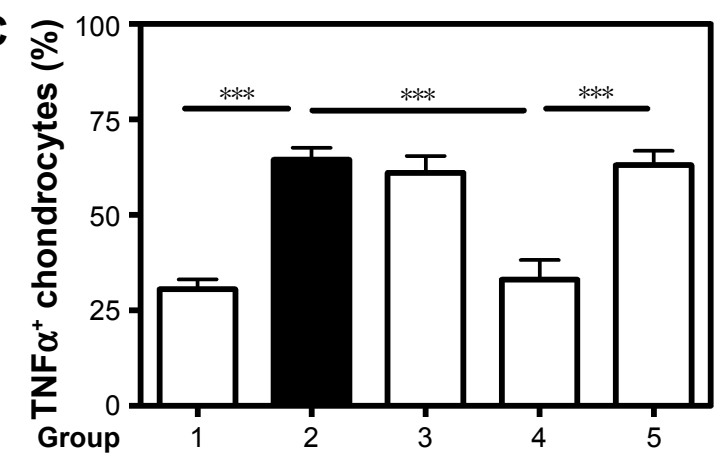

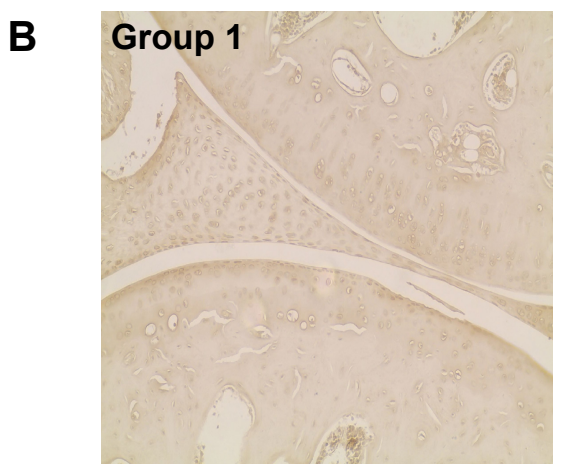

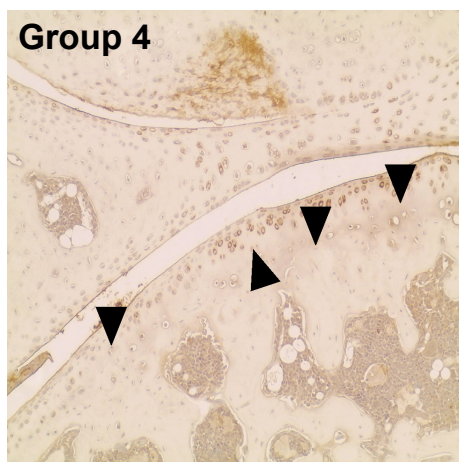

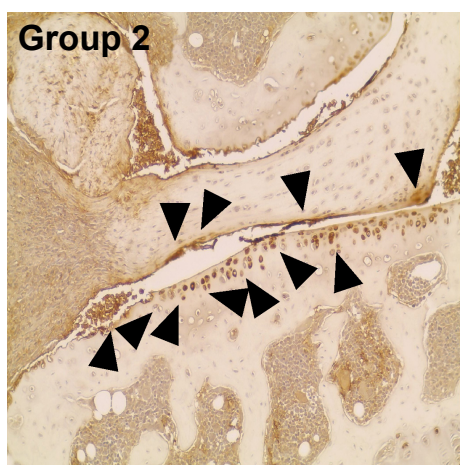

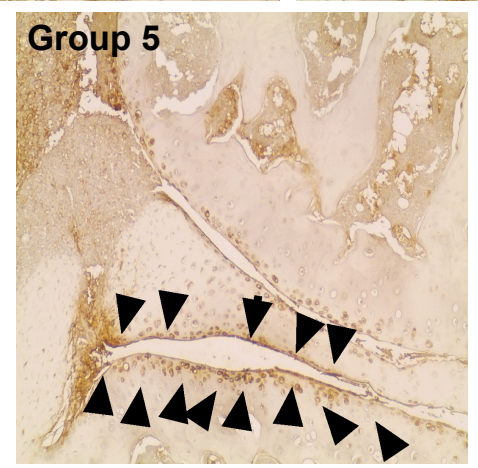

Figure 4 TNF $\alpha$ expression.

Notes: (A) TNF $\alpha$ concentrations were determined by ELISA in tissue homogenates of knee joints. (B) Immunostaining of TNF $\alpha$-positive chondrocytes (black arrows). (C) Total and positive-stained chondrocytes were counted and presented as percentages. Values are the means \pm SEM of eight mice (groups I-4) and five mice (group 5). Statistical significance was assessed by unpaired Student's t-test, $* P<0.05$, $* * P<0.01$, $* * * P<0.00$ I. Group I: normal control; group 2: CAIA control; group 3: CAIA mice treated with $\mathrm{CH}-\mathrm{DEAE} \mathrm{I}_{15} / \mathrm{siRNA}-\mathrm{TNF} \alpha$ nanoparticles; group 4: CAIA mice treated with folate-PEG-CH-DEAE 15 siRNA-TNF $\alpha$ nanoparticles; group 5: CAIA mice treated with siRNA-TNF $\alpha$.

Abbreviations: CAIA, collagen antibody-induced arthritis; $\mathrm{CH}$, chitosan; CTX-II, C-terminal telopeptide type II collagen; DEAE, diethylethylamine; ELISA, enzyme-linked immunosorbent assay; PEG, polyethylene glycol; SEM, standard error of the means; TNF $\alpha$, tumor necrosis factor-alpha. 
downregulate TNF $\alpha$ expression and the arthritic outcome in a murine CAIA model. We included folic acid groups because folate receptors are overexpressed on activated macrophages, playing a role in the inflammatory conditions seen in RA. ${ }^{48,49}$ Folic acid ligands increased CH/siRNA complex treatment efficiency in murine CAIA, which confirms our previous findings on an adjuvant-induced arthritis model. ${ }^{25}$

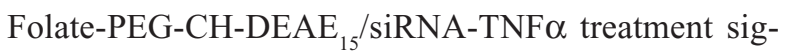
nificantly decreased arthritis, as indicated by clinical scores in comparison to normal and CAIA mice (Figure 2). Reduction of this arthritic condition was due to downregulation of TNF $\alpha$ expression in knee tissues, where its inhibition was evidenced by lining level (group 4; Figure 4). These results support the outcomes of other experimental studies, where TNF $\alpha$ knockdown controlled RA pathology.,22,50 TNF $\alpha$ silencing with peptide/siRNA complexes and $\mathrm{CH} /$ siRNA nanoparticles decreased joint pathology in CAIA and collagen-induced arthritis (CIA) models, respectively. ${ }^{2,22}$ TNF $\alpha$ knockdown with monoclonal antibodies also had good outcomes in murine $\mathrm{CIA}^{6}$ and is being used to treat patients. ${ }^{51}$ One potential pitfall of therapies involving TNF $\alpha$ monoclonal antibodies is the heightened risk of immune system impairment. ${ }^{52,53}$ In this respect, folate-CH nanoparticles offer the advantage of targeting folate receptors on activated cells, which decreases TNF $\alpha$ expression in affected tissues rather than in serum, lowering systemic risk.

Nontreated CAIA mice showed cartilage and bone destruction. Cartilage destruction was measured by quantifying serum CTX-II. Levels of the cartilage destruction marker were
A
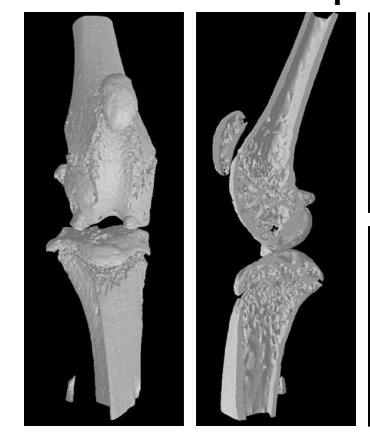

Group 3

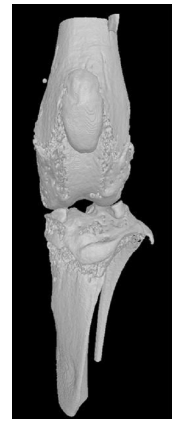

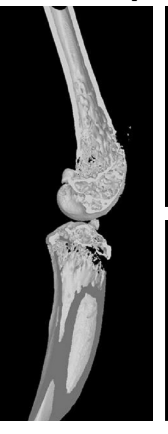
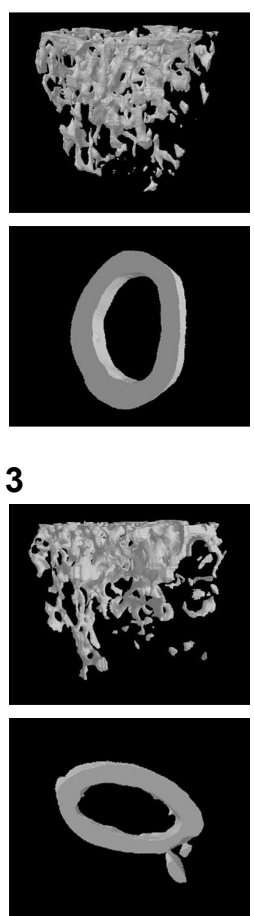

Group 2
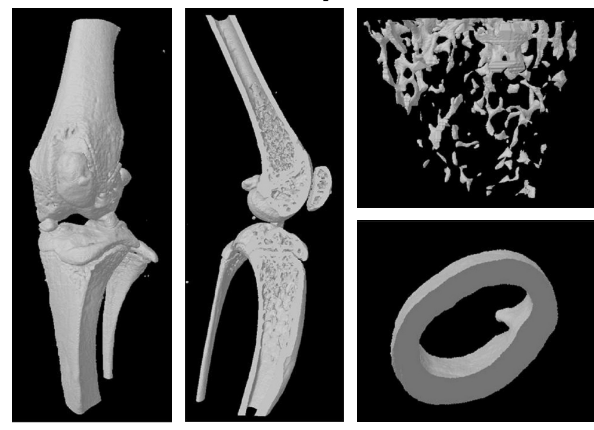

Group 4
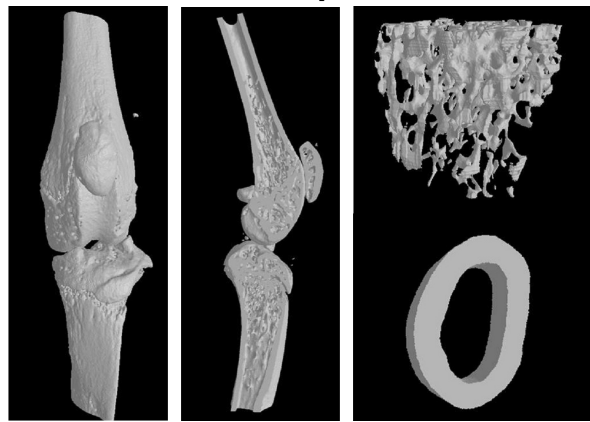

\section{Group 5}
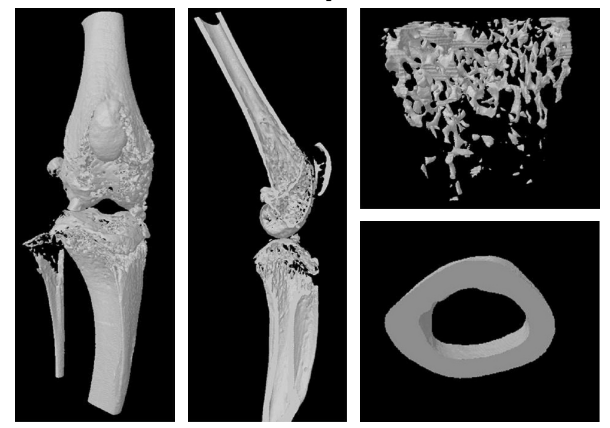

Figure 5 (Continued) 
B

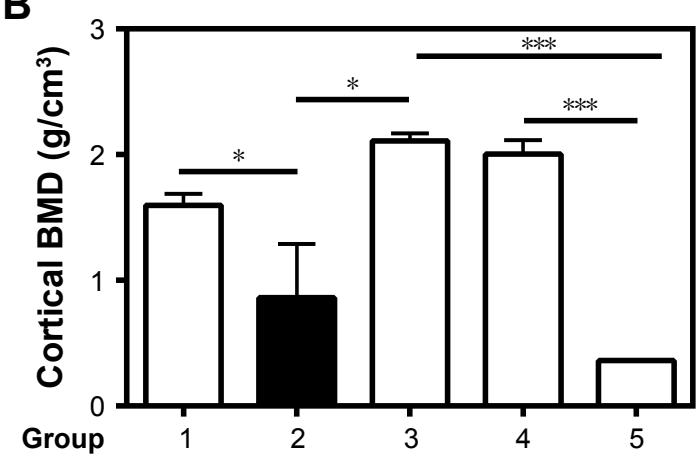

D

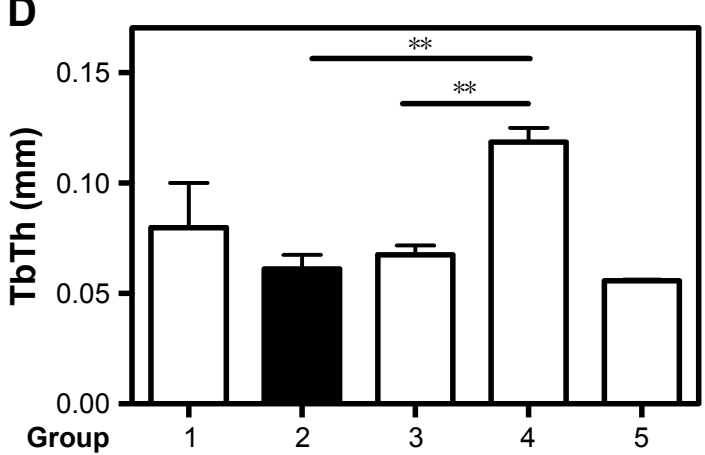

C

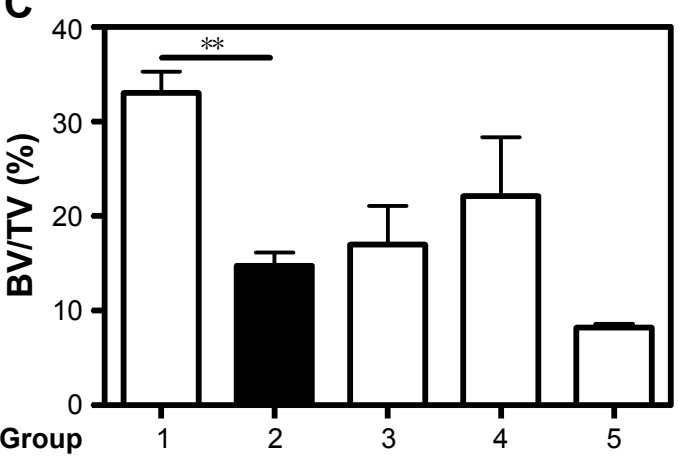

E

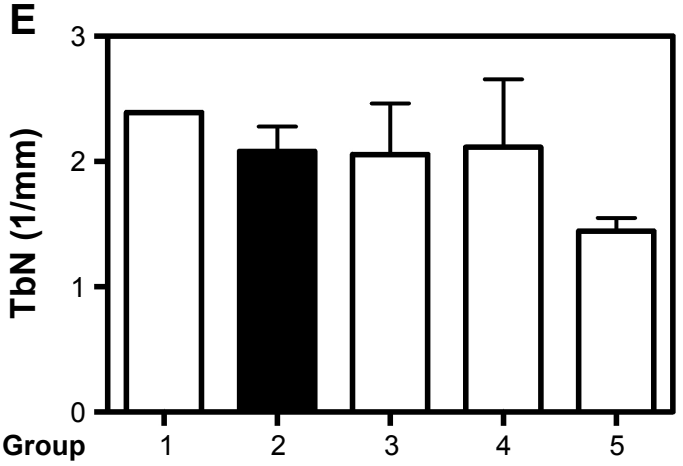

$\mathbf{F}$

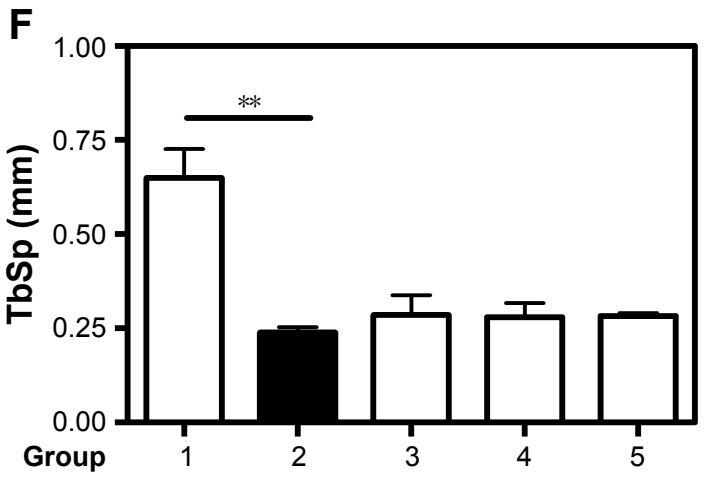

Figure 5 Micro-CT analysis.

Notes: (A) Representative trabecular bone in micro-CT images of the distal femur in mice from different groups. (B) Cortical BMD in femur diaphysis. (C) Trabecular bone volume as percentage of total volume (BV/TV). (D) TbTh. (E) TbN. (F) TbSp. $n=3$. Values are the means \pm SEM of three mice. Statistical significance was assessed by unpaired Student's t-test, ${ }^{*} P<0.05,{ }^{*} * \mathrm{P}<0.01$, ${ }^{* * *} \mathrm{P}<0.00 \mathrm{I}$. Group I: normal control; group 2: CAIA control; group 3: CAIA mice treated with CH-DEAE 15 /siRNA-TNF $\alpha$ nanoparticles; group 4: CAIA mice treated with folate-PEG-CH-DEAE 15 /siRNA-TNF $\alpha$ nanoparticles; group 5: CAIA mice treated with siRNA-TNF $\alpha$.

Abbreviations: BMD, bone mineral density; BV, bone volume; CAIA, collagen antibody-induced arthritis; CH, chitosan; CTX-II, C-terminal telopeptide type II collagen; DEAE, diethylethylamine; ELISA, enzyme-linked immunosorbent assay; micro-CT, micro-computed tomography; PEG, polyethylene glycol; SEM, standard error of the means; $\mathrm{TbN}$, trabecular bone number; TbSp, trabecular separation; TbTh, trabecular bone thickness; TNF $\alpha$, tumor necrosis factor-alpha; TV, tissue volume.

lower in CAIA mice treated with folate-PEG-CH-DEAE 15 / siRNA-TNF $\alpha$ nanoparticles than in nontreated CAIA mice (group 2), reflecting decreased joint cartilage destruction in these animals (Figure 3E). They also reflect macroscopic scores and histologic evidence (Figure 3A). The histologic findings demonstrated that all joints from CAIA mice without treatment had synovitis and cartilage structure abnormalities, such as surface fissures and loss of cells, while cartilage surfaces in normal mice were regular and contained abundant cells.

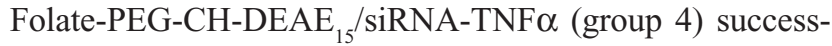
fully improved synovitis, bone erosion and cartilage destruction scores of joint pathology in CAIA mice (Figure 3B-D).

Bone remodeling is a process where osteoclast and osteoblast activities are synchronized to resorb old bone and synthesize new bone matrix, respectively ${ }^{54,55}$ Bone destruction is a typical characteristic of advanced RA.,44 Inflammation 
can generate inequality between both bone remodeling processes. ${ }^{5}$ ALP, PINP and OC biomarkers were measured to assess bone formation. ALP is a membrane protein the bonespecific form of which is known to be a biochemical marker of bone formation. ${ }^{56}$ PINP is a propeptide found in blood during type I collagen synthesis, providing proof of the bone matrix formation process. ${ }^{57,58} \mathrm{OC}$ is a protein synthesized by osteoblasts. ${ }^{59}$ Its presence in blood indicates that a part of OC does not bind to the bone matrix during bone formation ${ }^{60}$ or may reflect its release from the bone matrix during bone resorption. ${ }^{60,61}$ Serum OC levels are high in bone diseases, characterized by high bone turnover. ${ }^{61}$ OC may be important in recruiting and activating bone-resorbing cells. ${ }^{62,63}$

Our data demonstrated that serum ALP and PINP levels decreased in arthritic mice (group 2; Figure 6A and C), suggesting ongoing reduction of bone formation due to inflammation-induced bone destruction. These outcomes support previous findings where serum ALP ${ }^{42}$ and PINP levels decreased significantly, while serum OC levels increased in postmenopausal CIA mice. ${ }^{42}$ In this study, folate-PEG-CH-DEAE ${ }_{15} / \mathrm{siRNA}^{\mathrm{T}} \mathrm{TF} \alpha$ treatment augmented serum ALP and PINP concentrations, which led to a compensatory osteoblast response via coupling of bone formation and resorption, resulting in increased bone matrix

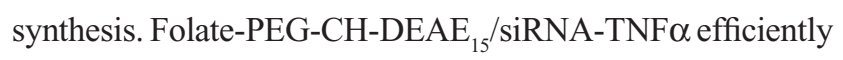

A

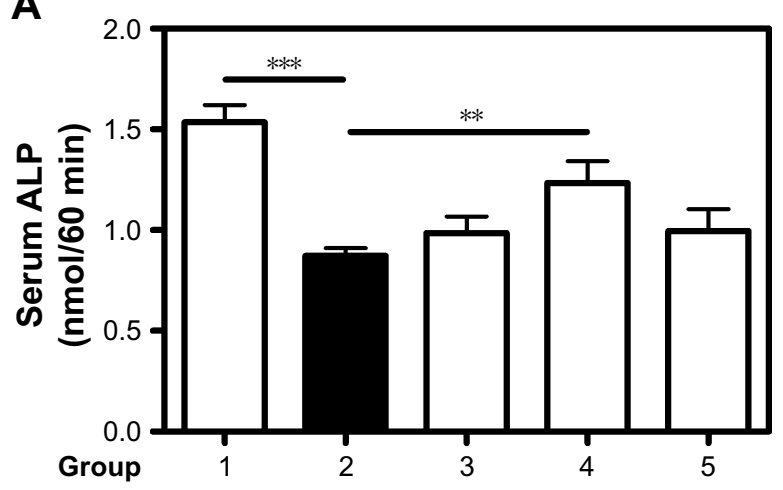

C

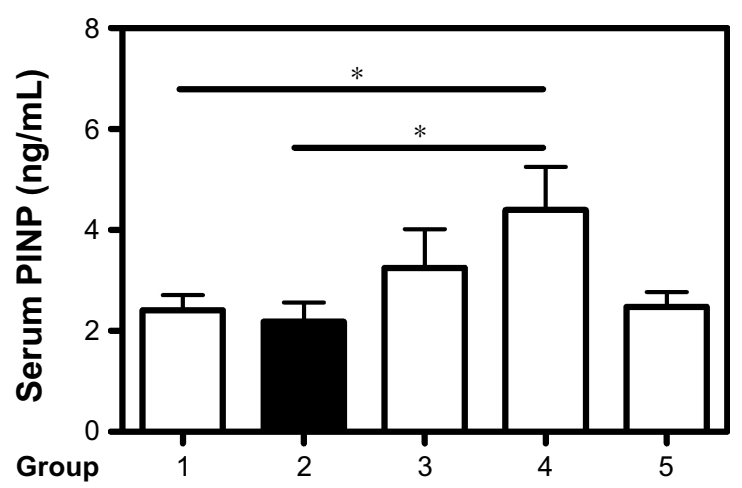

suppressed OC protein expression (Figure 6B), which slowed bone resorption. Serum OC and ALP levels do not always correlate in a similar way, reflecting their different roles ${ }^{61,64,65}$ during bone formation, namely, matrix development and mineralization, respectively. ${ }^{66}$

TRAP, a marker of osteoclast activity, ${ }^{67}$ was studied to verify bone resorption. Folate-CH-treated mice (group 4) showed reduced serum TRAP levels compared to arthritic mice (group 2; Figure 6D). Histochemical staining of mice joint sections disclosed that TRAP activity corresponded to abundance of TRAP-positive osteoclasts observed in arthritic tissues (group 2) where bone damage was evident (Figure 6E and F). The folate- $\mathrm{CH}$ group showed lower numbers of TRAP-positive cells and improved the bone structure (Figure 6E). These outcomes support previous findings in a study of adjuvant-induced arthritis rats. ${ }^{25}$

TNF $\alpha$ downregulation reduces inflammation and osteoporosis, the latter by decreasing osteoclast recruitment and activation, hence the resorptive effect. ${ }^{68}$ TNF $\alpha$ has also been recognized to activate and increase RANKL production, which has an impact on osteoclast formation. ${ }^{68,69}$ This cytokine influences osteoclast and osteoblast osteogenesis. ${ }^{68}$ For this reason, bone structure analysis is imperative to study the efficacy of anti-TNF $\alpha$ therapy. Bone microarchitecture is one of the parameters used to evaluate bone strength ${ }^{55}$
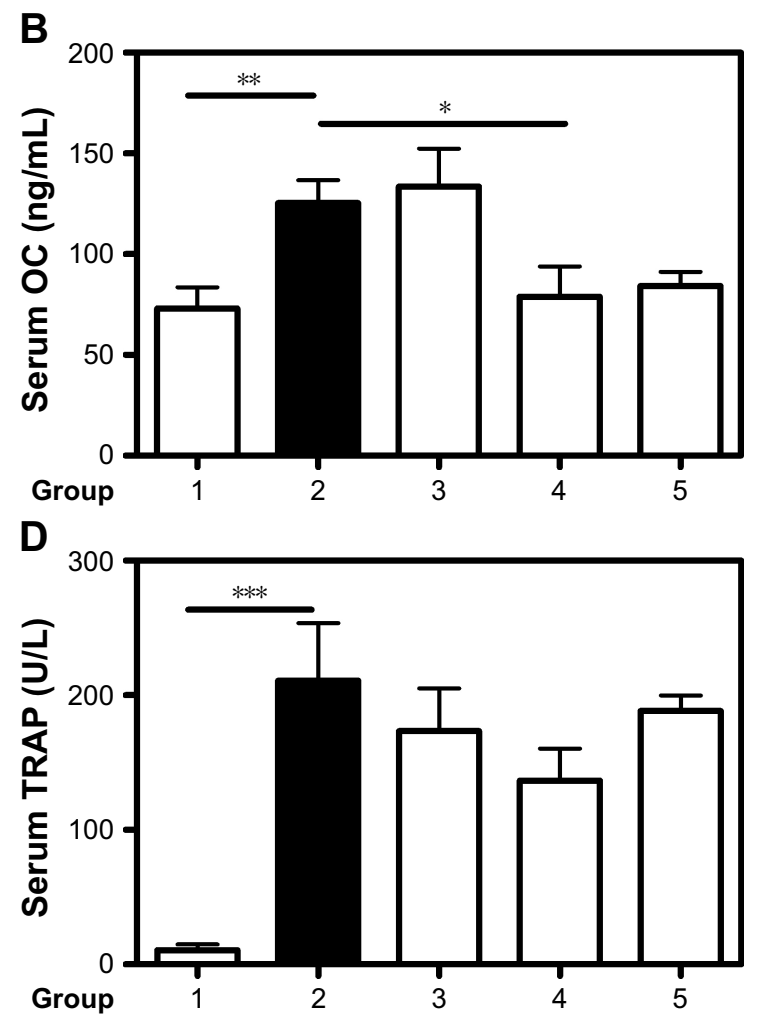

Figure 6 (Continued) 


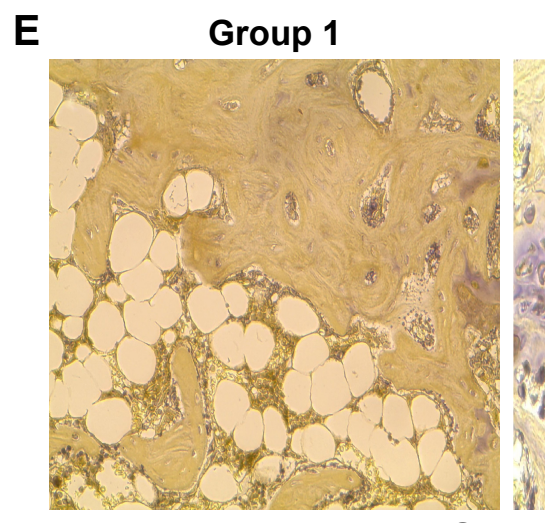

Group 2

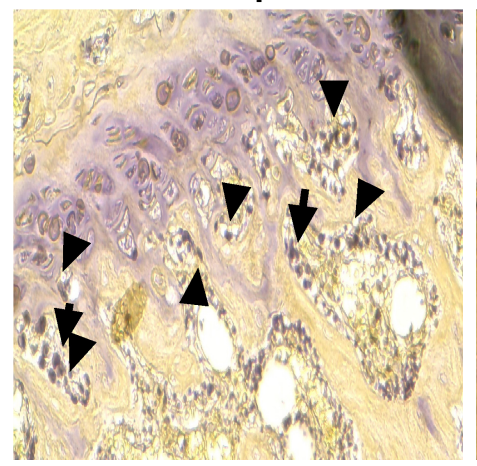

Group 3

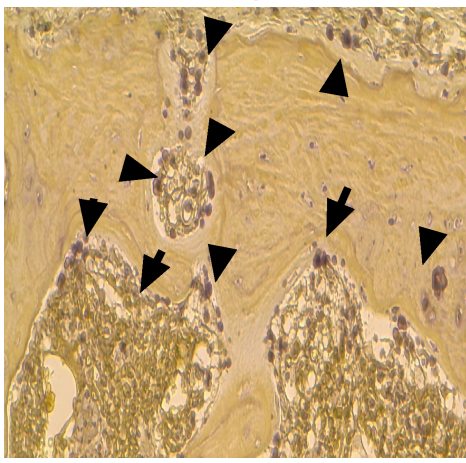

Group 5
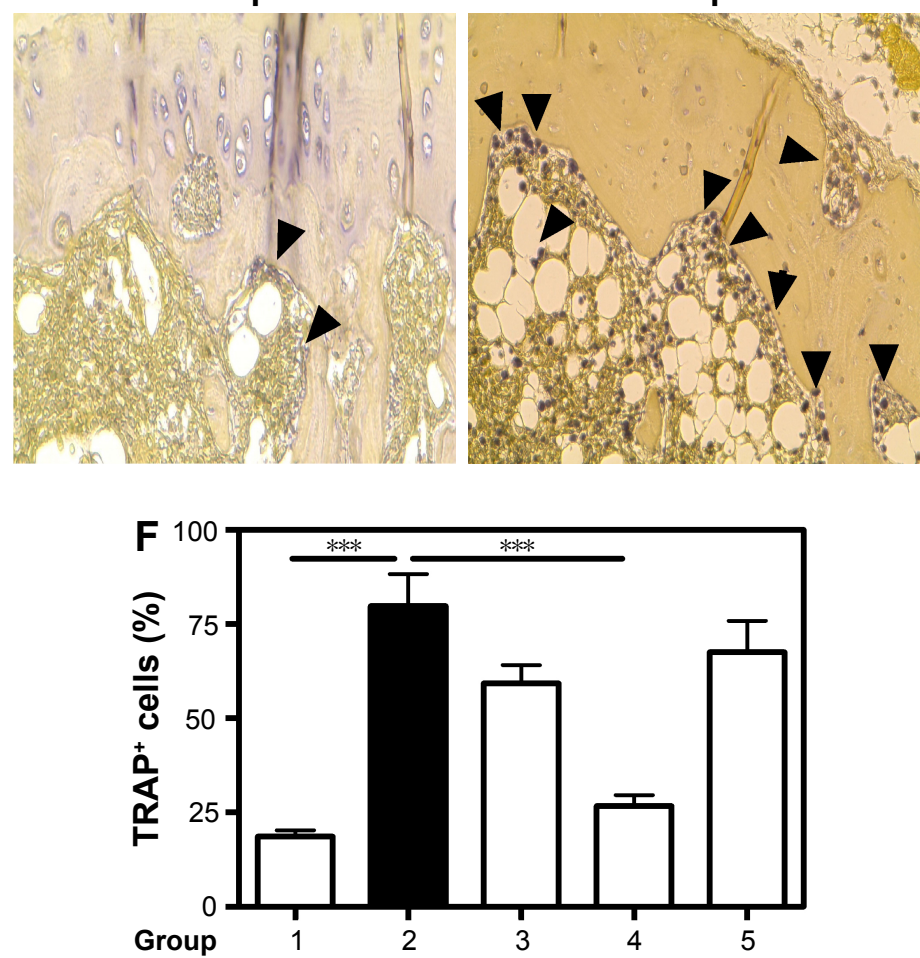

Figure 6 Biomarkers of bone formation and resorption.

Notes: Therapeutic effect of $\mathrm{CH}-\mathrm{DEAE} \mathrm{E}_{15} / \mathrm{siRNA}-\mathrm{TNF} \alpha$, folate-PEG-CH-DEAE 15 /siRNA-TNF $\alpha$ and naked siRNA-TNF $\alpha$ nanoparticles on serum bone marker levels in CAIA mice. (A) Serum ALP on day 10. (B) Serum OC on day 10. (C) Serum PINP on day 10. (D) Serum TRAP levels. (E) Immunostaining showing TRAP-positive cells indicated by black arrows. (F) Percentage of TRAP-positive cells in each group. Statistical significance was assessed by unpaired Student's $t$-test, $* P<0.05$, $* * P<0.0$ I, $* * * P<0.001$. Group I: normal control; group 2: CAIA control; group 3: CAIA mice treated with DEAE $15-\mathrm{CH} / \mathrm{siRNA}-\mathrm{TNF} \alpha$ nanoparticles; group 4: CAIA mice treated with folate-PEG-CH-DEAE 15 / siRNA-TNF $\alpha$ nanoparticles; group 5: CAIA mice treated with siRNA-TNF $\alpha$.

Abbreviations: ALP, alkaline phosphatase; CAIA, collagen antibody-induced arthritis; CH, chitosan; CTX-II, C-terminal telopeptide type II collagen; DEAE, diethylethylamine; ELISA, enzyme-linked immunosorbent assay; OC, osteocalcin; PEG, polyethylene glycol; PINP, procollagen I N-terminal peptide; SEM, standard error of the means; TNF $\alpha$, tumor necrosis factor-alpha; TRAP, tartrate-resistant acid phosphatase.

Table 3 Biomarkers of bone formation and bone resorption

\begin{tabular}{llllll}
\hline & $\begin{array}{l}\text { Serum ALP } \\
(\mathbf{n m o l} / 60 \mathbf{m i n})\end{array}$ & $\begin{array}{l}\text { Serum PINP } \\
(\mathbf{n g} / \mathbf{m L})\end{array}$ & $\begin{array}{l}\text { Serum OC } \\
(\mathbf{n g} / \mathbf{m L})\end{array}$ & Serum TRAP (U/L) & TRAP $^{+}$cells (\%) \\
\hline Group 1 & $1.54 \pm 0.08$ & $2.41 \pm 0.30$ & $73.02 \pm 10.64$ & $10.66 \pm 4.28$ & $18.67 \pm 1.65$ \\
Group 2 & $0.87^{\mathrm{a}} \pm 0.04$ & $2.19 \pm 0.38$ & $125.3^{\mathrm{b}} \pm 11.41$ & $210.8^{\mathrm{a}} \pm 42.67$ & $79.80^{\mathrm{a}} \pm 8.53$ \\
Group 3 & $0.99 \pm 0.08$ & $3.24 \pm 0.76$ & $133.6 \pm 18.8$ & $173.3 \pm 31.71$ & $59.33 \pm 4.75$ \\
Group 4 & $1.23^{\mathrm{c}} \pm 0.11$ & $4.40^{\mathrm{d}, \mathrm{e}} \pm 0.85$ & $78.98^{\mathrm{d}} \pm 14.90$ & $136.7 \pm 23.80$ & $26.69^{\mathrm{f}} \pm 2.95$ \\
Group 5 & $1.00 \pm 0.11$ & $2.47 \pm 0.29$ & $84.28 \pm 6.92$ & $188.3 \pm 11.56$ & $67.50 \pm 8.37$ \\
\hline
\end{tabular}

Notes: Group I: normal control; group 2: CAIA control; group 3: $\mathrm{CH}_{-} \mathrm{DEAE} / 1 / \mathrm{siRNA}-\mathrm{TNF} \alpha$-treated mice; group 4: folate-PEG-CH-DEAE 15 /siRNA-TNF $\alpha-$ treated mice; group 5: siRNA-TNF $\alpha$-treated mice. The data are expressed as means \pm SEM. Groups I-4: eight mice each; group 5: five mice. ${ }^{a} P<0.001$ compared to normal mice. ${ }^{b} P<0.01$ compared to normal mice. ${ }^{c} P<0.01$ compared to CAIA mice. ${ }^{d} P<0.05$ compared to CAIA mice. ${ }^{\text {e }}<<0.05$ compared to normal mice. ${ }^{f} P<0.001$ compared to CAIA mice. Abbreviations: ALP, alkaline phosphatase; CAIA, collagen antibody-induced arthritis; CH, chitosan; DEAE, diethylethylamine; OC, osteocalcin; PEG, polyethylene glycol; PINP, procollagen I N-terminal peptide; SEM, standard error of the means; TNF $\alpha$, tumor necrosis factor-alpha; TRAP, tartrate-resistant acid phosphatase. 
and, in this investigation, it was verified by $3 \mathrm{D}$ micro-CT analysis. Our results showed significant bone loss and structural alterations on day 10 in CAIA mice (group 2), based on significant reduction of cortical BMD (Figure 5B) and $\mathrm{BV} / \mathrm{TV}$ (Figure 5C), compared to the normal controls (group 1). Interestingly, animals treated with folate-PEG$\mathrm{CH}_{-\mathrm{DEAE}} / \mathrm{siRNA} \mathrm{TNF} \alpha$ nanoparticles maintained bone quality (improved cortical BMD and increased TbTh in a significant way in comparison to CAIA mice; Figure 5B and D). Enhancement of bone parameter outcomes by folate- $\mathrm{CH}$ nanocarriers was supported by decreased bone erosion scores (Figure 3C) and bone metabolism markers (Figure 5).

\section{Conclusion}

In conclusion, TNF $\alpha$ silencing by folate-PEG-CH-DEAE ${ }_{15} /$ siRNA nanoparticles is a potentially new approach to RA treatment. The results obtained in this study support previous findings on the capacity of folate-targeted $\mathrm{CH}$-siRNA/DNA nanoparticles to control inflammation as well as bone and cartilage destruction.

\section{Acknowledgments}

The authors thank Dr Daniel Lajeunesse (Université de Montréal) for his critical review of the manuscript, Ms Caroline Bouchard for animal handling-treatment and Mr Ovid Da Silva for manuscript editing. This work was supported, in part, by grants from the Science and Technology Commission of Shanghai Municipality (No 16430723500), Ministère de l'Économie, de la Science et de l'Innovation du Québec (Programme de soutien à la recherche [PSR], volet 4: Soutien à des initiatives internationales de recherche et d'innovation [SIIRI], 2017-2020), Canadian Institutes of Health Research (CCM 104888), and CNPq (grant 407499/2013-0). This study was conducted in Montréal, QC, Canada, and São Jose do Rio Preto, SP, Brazil.

\section{Availability of data and materials}

Supporting data are available as the authors have full access to all study data.

\section{Disclosure}

JCF, MJT, QS, MB and IPDP have filed for a patent on the nanoparticles described in this study. The authors report no other conflicts of interest in this work.

\section{References}

1. Asquith DL, Miller AM, McInnes IB, et al. Animal models of rheumatoid arthritis. Eur J Immunol. 2009;39(8):2040-2044.
2. Ye C, Bhan A, Deshpande V, et al. Silencing TNF- $\alpha$ in macrophages and dendritic cells for arthritis treatment. Scand J Rheumatol. 2013; 42(4):266-269.

3. Marenzana M, Vugler A, Moore A, Robinson M. Effect of sclerostinneutralising antibody on periarticular and systemic bone in a murine model of rheumatoid arthritis: a microCT study. Arthritis Res Ther. 2013;15(5):R125.

4. Scott D. Prognostic factors in early rheumatoid arthritis. Rheumatology (Oxford, England). 2000;39:24-29.

5. Goldring SR, Gravallese EM. Mechanisms of bone loss in inflammatory arthritis: diagnosis and therapeutic implications. Arthritis Res. 2000;2(1):33-37.

6. Williams RO, Feldmann M, Maini RN. Anti-tumor necrosis factor ameliorates joint disease in murine collagen-induced arthritis. Proc Natl Acad Sci U S A. 1992;89(20):9784-9788.

7. Paquet J, Henrionnet C, Pinzano A, et al. Alternative for anti-TNF antibodies for arthritis treatment. Mol Ther. 2011;19(10):1887-1895.

8. Buch MH, Pavitt S, Parmar M, Emery P. Creative trial design in RA: optimizing patient outcomes. Nat Rev Rheumatol. 2013;9(3):183-194.

9. van Schouwenburg PA, Rispens T, Wolbink GJ. Immunogenicity of anti-TNF biologic therapies for rheumatoid arthritis. Nat Rev Rheumatol. 2013;9(3):164-172.

10. Bender AT, Spyvee M, Satoh T, et al. Evaluation of a candidate antiarthritic drug using the mouse collagen antibody induced arthritis model and clinically relevant biomarkers. Am J Transl Res. 2013;5(1):92.

11. Mehta G, Scheinman RI, Holers VM, Banda NK. A new approach for the treatment of arthritis in mice with a novel conjugate of an anti-C5aR1 antibody and C5 small interfering RNA. J Immunol. 2015;194(11): $5446-5454$

12. Hamamura K, Nishimura A, Chen A, et al. Salubrinal acts as a Dusp2 inhibitor and suppresses inflammation in anti-collagen antibodyinduced arthritis. Cell Signal. 2015;27(4):828-835.

13. Schiffelers RM, Xu J, Storm G, et al. Effects of treatment with small interfering RNA on joint inflammation in mice with collagen-induced arthritis. Arthritis Rheum. 2005;52(4):1314-1318.

14. Shi Q, Tiera MJ, Zhang X, et al. Chitosan-DNA/siRNA nanoparticles for gene therapy. Non-Viral Gene Ther. 2011;19:455-480.

15. Tiera MJ, Shi Q, Barbosa HF, Fernandes JC. Polymeric systems as nanodevices for siRNA delivery. Curr Gene Ther. 2013;13(5):358-369.

16. Xiang S, Su J, Tong H, et al. Biscarbamate cross-linked low molecular weight PEI for delivering IL-1 receptor antagonist gene to synoviocytes for arthritis therapy. Biomaterials. 2012;33(27):6520-6532.

17. Castanotto D, Rossi JJ. The promises and pitfalls of RNA-interferencebased therapeutics. Nature. 2009;457(7228):426-433.

18. Gary DJ, Puri N, Won YY. Polymer-based siRNA delivery: perspectives on the fundamental and phenomenological distinctions from polymerbased DNA delivery. J Control Release. 2007;121(1-2):64-73.

19. Gao X, Kim KS, Liu D. Nonviral gene delivery: what we know and what is next. AAPS J. 2007;9(1):E92-E104.

20. Joo MK, Yhee JY, Kim SH, Kim K. The potential and advances in RNAi therapy: chemical and structural modifications of siRNA molecules and use of biocompatible nanocarriers. J Control Release. 2014; 193:113-121.

21. Andersen MO, Howard KA, Kjems J. RNAi using a chitosan/siRNA nanoparticle system: in vitro and in vivo applications. Methods Mol Biol. 2009;555:77-86.

22. Howard KA, Paludan SR, Behlke MA, et al. Chitosan/siRNA nanoparticle-mediated TNF-alpha knockdown in peritoneal macrophages for anti-inflammatory treatment in a murine arthritis model. Mol Ther. 2009;17(1):162-168.

23. Lee SJ, Lee A, Hwang SR, et al. TNF-alpha gene silencing using polymerized siRNA/thiolated glycol chitosan nanoparticles for rheumatoid arthritis. Mol Ther. 2014;22(2):397-408.

24. Katas H, Alpar HO. Development and characterisation of chitosan nanoparticles for siRNA delivery. J Control Release. 2006;115(2): 216-225. 
25. Fernandes JC, Wang H, Jreyssaty C, et al. Bone-protective effects of nonviral gene therapy with Folate-Chitosan DNA nanoparticle containing Interleukin-1 receptor antagonist gene in rats with adjuvant-induced arthritis. Mol Ther. 2008;16(7):1243-1251.

26. Sudimack J, Lee RJ. Targeted drug delivery via the folate receptor. Adv Drug Deliv Rev. 2000;41(2):147-162.

27. Yang C, Gao S, Kjems J. Folic acid conjugated chitosan for targeted delivery of siRNA to activated macrophages in vitro and in vivo. J Mater Chem B. 2014;2(48):8608-8615.

28. Oliveira FdPP, Dalla Picola IP, Shi Q, et al. Synthesis and evaluation of diethylethylamine chitosan for gene delivery: composition effects on the in vitro transfection efficiency. Nanotechnology. 2013; 24(5):055101.

29. de Oliveira PR, Takaki M, Gorayeb TC, et al. Synthesis, characterization and antifungal activity of quaternary derivatives of chitosan on Aspergillus flavus. Microbiol Res. 2013;168(1):50-55.

30. Khachigian LM. Collagen antibody-induced arthritis. Nat Protoc. 2006; 1(5):2512-2516

31. Cho KC, Jeong JH, Chung HJ, et al. Folate receptor-mediated intracellular delivery of recombinant caspase-3 for inducing apoptosis. $J$ Control Release. 2005;108(1):121-131.

32. Fernandes JC, Qiu X, Winnik FM, et al. Low molecular weight chitosan conjugated with folate for siRNA delivery in vitro: optimization studies. Int J Nanomedicine. 2012;7:5833.

33. Yang C, Gao S, Dagnaes-Hansen F, Jakobsen M, Kjems J. Impact of PEG chain length on the physical properties and bioactivity of PEGylated chitosan/siRNA nanoparticles in vitro and in vivo. ACS Appl Mater Interfaces. 2017;9(14):12203-12216.

34. Malmo J, Sorgard H, Varum KM, Strand SP. siRNA delivery with chitosan nanoparticles: molecular properties favoring efficient gene silencing. J Control Release. 2012;158(2):261-268.

35. Tavakoli Naeini A, Soliman OY, Alameh MG, Lavertu M, Buschmann MD. Automated in-line mixing system for large scale production of chitosan-based polyplexes. J Colloid Interface Sci. 2017;500: 253-263.

36. Shi Q, Abusarah J, Baroudi G, et al. Ramipril attenuates lipid peroxidation and cardiac fibrosis in an experimental model of rheumatoid arthritis. Arthritis Res Ther. 2012;14(5):R223.

37. Wisłowska M, Jakubicz D, Stępień K, Cicha M. Serum concentrations of formation (PINP) and resorption (Ctx) bone turnover markers in rheumatoid arthritis. Rheumatol Int. 2009;29(12):1403-1409.

38. Shi Q, Vaillancourt F, Côté V, et al. Alterations of metabolic activity in human osteoarthritic osteoblasts by lipid peroxidation end product 4-hydroxynonenal. Arthritis Res Ther. 2006;8(6):R159.

39. Bas DB, Su J, Sandor K, et al. Collagen antibody-induced arthritis evokes persistent pain with spinal glial involvement and transient prostaglandin dependency. Arthritis Rheum. 2012;64(12): 3886-3896.

40. Király K, Lapveteläinen T, Arokoski J, et al. Application of selected cationic dyes for the semiquantitative estimation of glycosaminoglycans in histological sections of articular cartilage by microspectrophotometry. Histochem J. 1996;28(8):577-590.

41. Boileau C, Martel-Pelletier J, Caron J, et al. Protective effects of total fraction of avocado/soybean unsaponifiables on the structural changes in experimental dog osteoarthritis: inhibition of nitric oxide synthase and matrix metalloproteinase-13. Arthritis Res Ther. 2009;11(2):R41.

42. Ibanez L, Alcaraz MJ, Maicas N, et al. Downregulation of the inflammatory response by CORM-3 results in protective effects in a model of postmenopausal arthritis. Calcif Tissue Int. 2012;91(1): 69-80.

43. Oestergaard S, Chouinard L, Doyle N, et al. The utility of measuring C-terminal telopeptides of collagen type II (CTX-II) in serum and synovial fluid samples for estimation of articular cartilage status in experimental models of destructive joint diseases. Osteoarthritis Cartilage. 2006;14(7):670-679.
44. Ramprasath VR, Shanthi P, Sachdanandam P. Curative effect of Semecarpus anacardium Linn. nut milk extract against adjuvant arthritis with special reference to bone metabolism. Chem Biol Interact. 2006; 160(3):183-192.

45. Romas E, Bakharevski O, Hards DK, et al. Expression of osteoclast differentiation factor at sites of bone erosion in collagen-induced arthritis. Arthritis Rheum. 2000;43(4):821.

46. Rojanarata T, Petchsangsai M, Opanasopit P, et al. Methylated N-(4$\mathrm{N}, \mathrm{N}$-dimethylaminobenzyl) chitosan for novel effective gene carriers. Eur J Pharm Biopharm. 2008;70(1):207-214.

47. Liu X, Howard KA, Dong M, et al. The influence of polymeric properties on chitosan/siRNA nanoparticle formulation and gene silencing. Biomaterials. 2007;28(6):1280-1288.

48. Low PS, Antony AC. Folate receptor-targeted drugs for cancer and inflammatory diseases. Adv Drug Deliv Rev. 2004;56(8):1055-1058.

49. Turk MJ, Breur GJ, Widmer WR, et al. Folate-targeted imaging of activated macrophages in rats with adjuvant-induced arthritis. Arthritis Rheum. 2002;46(7):1947-1955.

50. Smolen JS, Aletaha D, Koeller M, et al. New therapies for treatment of rheumatoid arthritis. Lancet. 2007;370(9602):1861-1874.

51. Wiens A, Venson R, Correr CJ, et al. Meta-analysis of the efficacy and safety of adalimumab, etanercept, and infliximab for the treatment of rheumatoid arthritis. Pharmacotherapy. 2010;30(4):339-353.

52. Komano Y, Tanaka M, Nanki T, et al. Incidence and risk factors for serious infection in patients with rheumatoid arthritis treated with tumor necrosis factor inhibitors: a report from the registry of Japanese rheumatoid arthritis patients for longterm safety. J Rheumatol. 2011;38(7): $1258-1264$.

53. Komano Y, Yagi N, Onoue I, et al. Arthritic joint-targeting small interfering RNA-encapsulated liposome: implication for treatment strategy for rheumatoid arthritis. J Pharmacol Exp Ther. 2012;340(1):109-113.

54. Baim S, Miller PD. Assessing the clinical utility of serum CTX in postmenopausal osteoporosis and its use in predicting risk of osteonecrosis of the jaw. J Bone Miner Res. 2009;24(4):561-574.

55. Liu WC, Yen JF, Lang CL, et al. Bisphophonates in CKD patients with low bone mineral density. Sci World J. 2013;2013:837573.

56. Lehman MA, Kream J, Brogma D. Acid and alkaline phosphatase activity in the serum and synovial fluid of patients with arthritis. $J$ Bone Joint Surg Am. 1964;46(8):1732-1738.

57. Risteli L, Risteli J. Analysis of extracellular matrix proteins in biological fluids. Methods Enzymol. 1987;145:391-411.

58. Melkko J, Kauppila S, Niemi S, et al. Immunoassay for intact aminoterminal propeptide of human type I procollagen. Clin Chem. 1996; 42(6 Pt 1):947-954.

59. Lian JB, Gundberg CM. Osteocalcin. Biochemical considerations and clinical applications. Clin Orthop Relat Res. 1988;(226):267-291.

60. Seibel M. Molecular markers of bone turnover: biochemical, technical and analytical aspects. Osteoporos Int. 2000;11(18):S18-S29.

61. Swaminathan R. Biochemical markers of bone turnover. Clinica Chimica Acta. 2001;313(1):95-105.

62. Hauschka PV, Lian JB, Cole DE, Gundberg CM. Osteocalcin and matrix Gla protein: vitamin K-dependent proteins in bone. Physiol Rev. 1989;69(3):990-1047.

63. Glowacki J, Rey C, Glimcher M, et al. A role for osteocalcin in osteoclast differentiation. J Cell Biochem. 1991;45(3):292-302.

64. Gundberg CM. Biochemical markers of bone formation. Clin Lab Med. 2000;20(3):489-501.

65. Díaz DE, Díaz MM, de la Piedra C, Rapado A. Lack of correlation between levels of osteocalcin and bone alkaline phosphatase in healthy control and postmenopausal osteoporotic women. Horm Metab Res. 1995;27(3):151-154.

66. Bikle DD. Biochemical markers in the assessment of bone disease. Am J Med. 1997;103(5):427-436.

67. Janckila AJ, Neustadt DH, Nakasato YR, et al. Serum tartrate-resistant acid phosphatase isoforms in rheumatoid arthritis. Clinica Chimica Acta. 2002;320(1):49-58. 
68. Kawai VK, Stein CM, Perrien DS, Griffin MR. Effects of anti-tumor necrosis factor $\alpha$ (anti-TNF) agents on bone. Curr Opin Rheumatol. 2012;24(5):576
69. Weitzmann MN. The role of inflammatory cytokines, the RANKL/OPG axis, and the immunoskeletal interface in physiological bone turnover and osteoporosis. Scientifica. 2013;2013:125705.

\section{Publish your work in this journal}

The International Journal of Nanomedicine is an international, peerreviewed journal focusing on the application of nanotechnology in diagnostics, therapeutics, and drug delivery systems throughout the biomedical field. This journal is indexed on PubMed Central, MedLine, CAS, SciSearch ${ }^{\circledR}$, Current Contents ${ }^{\circledR} /$ Clinical Medicine, Elsevier Bibliographic databases. The manuscript management system is completely online and includes a very quick and fair peer-review system, which is all easy to use. Visit http://www.dovepress.com/ testimonials.php to read real quotes from published authors.

Submit your manuscript here: http://www.dovepress.com/international-journal-of-nanomedicine-journal 